\title{
The Shoes You Wear
}

\section{Why They are Moderate in Price and Good in Quality}

By George Brockholst

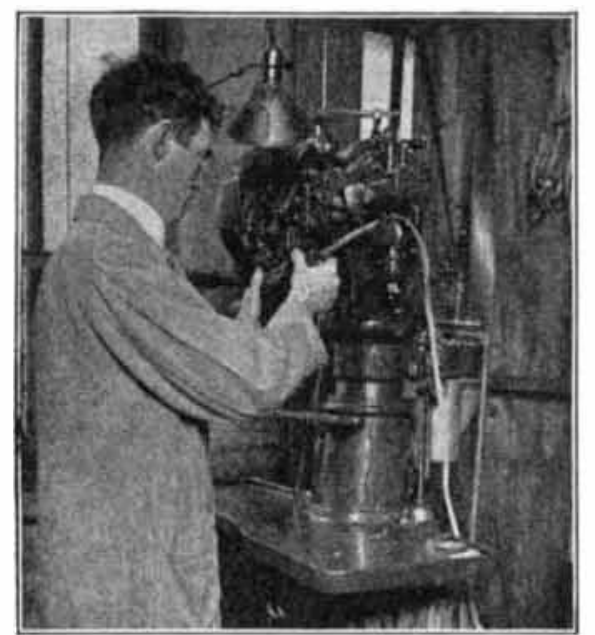

The Goodyear welter, which has been the leading factor in revolutionizin shoemaking and which has done much to reduce the price of shoes.

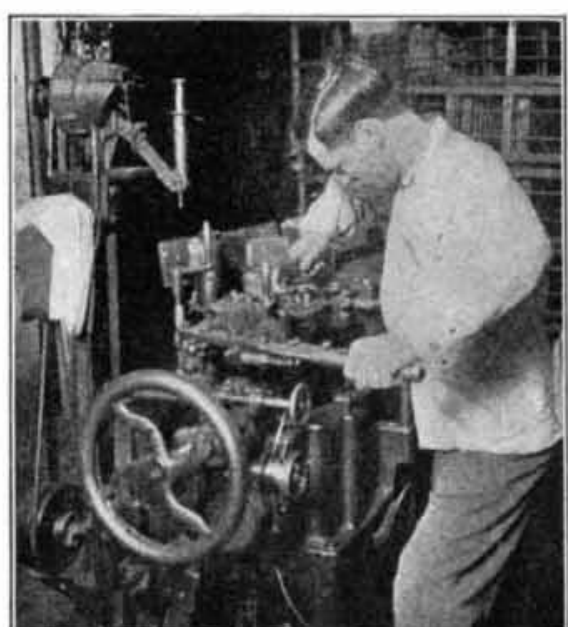

This lasting machine is provided with wipers for toe and heel, which draw the leather from all directions so that no wrinkles show on the shoe.

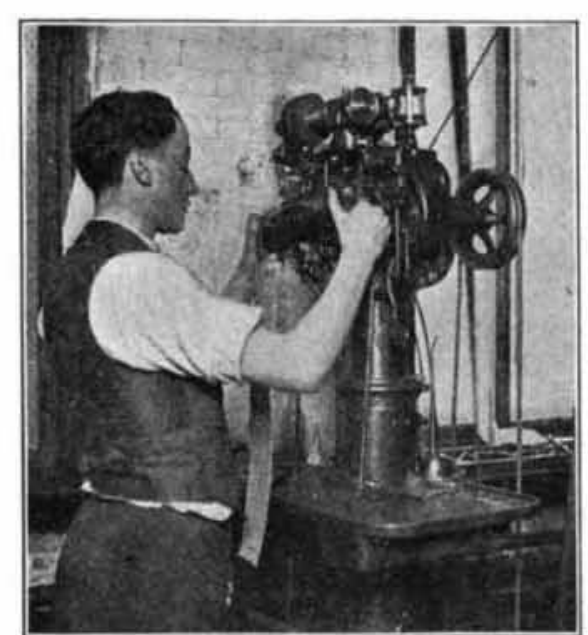

A rounding and channeling machin is employed in cutting the outsole to conform with the shape of the bottom of the last with any desired extensions.

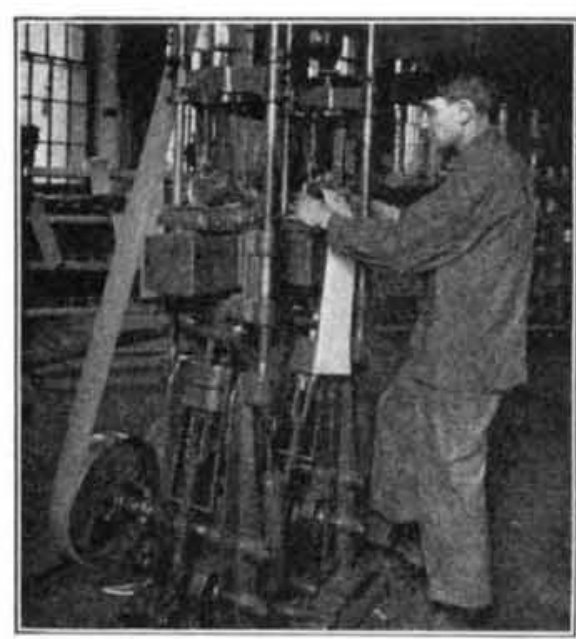

Goodyear improved sole-laying machine, which fastens the cemented soles to the shoe-bottom without tacks so as to leave a clean bottom.
The first fact that everyone should know about shoes is this:

SHOES ARE BETTER IN QUALITY NOW THAN THEY EVER WERE AND VERY NEARLY AS CHEAI. Every other necessity of life has increased much more in cost.

Another fact:

SHOES ARE NOT MADE BY A TRUST. No less than 1,200 factories are keenly competing with one another.

There must be some reason why shoes have not in creased very much in price and why there is no shoe trust.

There is just one and only one reason and that is: THE EFFECTIVE SERVICE POLICY OF THE UNITED SHOE MACHINERY COMPANY.

HOW THE UNITED SHOE MACHINERY COMPANY WAS STARTED.

The United Shoe Nachinery Company was organized in 1899. It was formed for the purpose of enabling shoe manuficturers to make bettcr shoes than they made before and to scll them to the public at the smallcst possible expensc.

Before the Inited Shoe Machinery Company was organized, three important companies were supplying manufacturers with shoe machinery. THE CONPANIES WERE NOT COMPETITORS, because each made a class of machines for a special purpose.

Thus, the Goodyear Shoe Machinery Company made machines which uroduced what are known as "welt" shoes. like those once sewn by hand. In sewing a shoe by hand, a thin and narrow stril of leather called a "welt" is first stitched to the insole and ulper. The heavy out sole is then sewed to this welt, so that the stitches fall outside and do not touch the foot, the insole being left entirely smooth. The welting and stitching machines of the Goodvear Company-nam of the Goodvear com and was a soll of the inventor of the Goodyear rubbervulcanizing process-completely displaced hand sewing. The welt shoe made on the Goodyear machines is the most comfortable shoe sold to-day-the finest product of the American shoe industry.

Besides the Goodyear Shoe Machinery Company, there were in the field the Consolidated and McLay Lasting Machine Company and the McKay Shoe Machinery Company. The Consolidated and McKay Lasting Machine Company made machines for lasting a shoe, a totally different operation from that performed by the Goodyear machines. The McKay Shoe Machinery Company made machines for attaching soles and heels by metallic fasteners.

These three companies did not sell their machines to shoe manufacturers, but leased them and charged a roya lty for their use. So long as the machines were in use they earned money for their minufacturers and for shoe makers. It was very necessary that they should not remain idle for a long time. Hence each of these companies established a repair service to keep its leased machines in good running order.

Here were three NON-COMPETING companies dealing with the same shoe manufacturers and sending out three sets of repair men to the same factories. Clearly, there was an unnecessary duplication of expense, for all of which the shoe manufacturer and ultimately the public paid. One set of repair men could easily keep all the machines of the three companies in order. One factory could easily make all three NON-CONLETING types of machines, so that the shoe manufacturer could obtain his erfuipment from one source, just as housewives can obtain non-competing carpet sweepers and gloves or non-competing washboards and linen from a single department store.

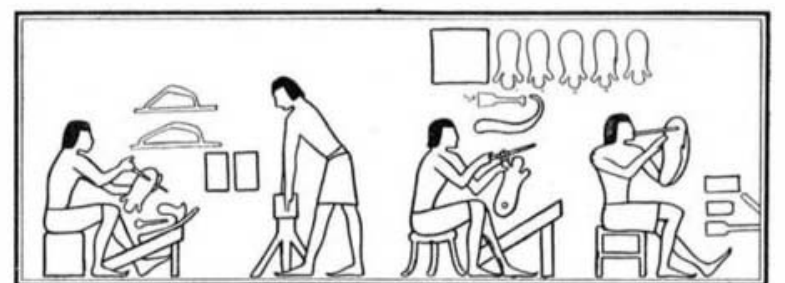

This reproduction of an ancient decoration shows that, thousands of years ago, the Egyptian made shoes very much as the modern cobbler did before the invention of American shoe machinery.

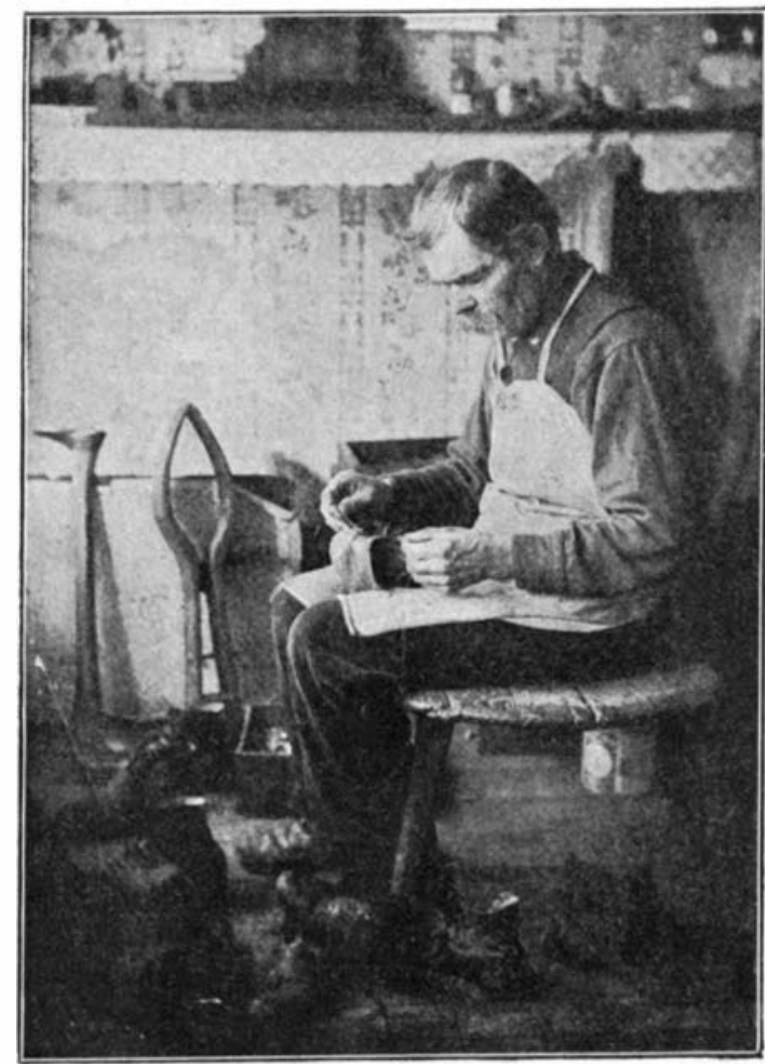

From Dooley's “ Mantal of Shoemaling" by courtesy of Little, Brown \& Co.

An interval of thousands of years separates this picture from the Egyptian hieroglyphics above. Yet the method of shoemaking disclosed is the same. More progress has been made in the last generation, because of the systematic development of machinery in this country, than in the preceding fifty centuries.
So, in order to lessen the expense of making shoes AND IN ORDER TO ENABLI TIIE PI'BLIC TO BUY TIIE BEST SIIOES AT TIIE LOWLST I'RICE the three NON-COMI'ETING firms mentioned were cousolidated in 1899 to form the United Shoe Milchinery Company.

\section{THE BENEFITS OF THE LEASING SYSTEM.}

liecause the old leissing sistem has been continued by the Inited Shoe Machinery Compiny, there is no shoe trust. You will understand why if you consider the way most manuficturers nust start in business. Suppose that you had decided to engilge ill a minu. facturing enterırise. You would have to raise money not only for the purplose of accuiring a factory, but also of purchasing machinery. Indeed, you would spend much money on machinery-so much that when you sold your goods, you would have to make a proportional charge for the interest on the money invested in the machinery-about six per cent a year-and another ten per cent a year for delureciation, rejairs and the like. Because these fixed chirres are large. because it takes much money to buy expensive michinery, many important industrics - textile manufacturing, for example-are concintrated in the hands of a few com panics. COMIETITION IS LIMITED.

This applies to nearly every industry EXCEI"] SHOE MANUFACTURING. The United Shoe Machin ery Company's leasing method renders it possible to obtain the most modern equipment for a small outlay, so that the manufacturer can use his money over ancl over again in buying raw material and selling shoes. He doc's not have to make a charge for interest on money invested in shoe machincry or for the deprecio tion of the machincry.

TILAT IS ONE OF THE CHIEF REASONS WIIY YOIR SIIOES ARE SO CHEAP. TIIAT IS ONE (OH THE CHIEF REASONS WHY THISRE IS NO SHOI TRUST.

TIIE SHOE MANUFACTLREI PAYS ONLY FOI THE WORK THE MACIIINE DOES, just as he pily only for the work that a min does.

WHY THERE IS NO SHOE TRUST.

THE IINITED SHOS MACHINERY CONIPAN DEALS WITH ALL SHOE MANUFACTIRL: ALIKE. It matters not whether a man his a cilpitil of a million dollars or only ten thousand dollars.

Big shoe manufacturers have tried to obtain what they call "better terms" from the Vnited Shoe Macilinery Company, because they use so much more malchinery than the small manufacturer. If the I'nited shoe Machinery Company had listened to this argumen there would be only a few large factories engilged in shoe manufacturing to-day, AND NO SUILL Wil TORIES. As it is, the man with only a fal: thousunil dollars capital is able to competc with the millionaire. THAT IS ANOTHER REASON WUIY THERE IS NO SHOE TRUST.

ONE AND ONE-THIRD CENTS A PAIR

Of the three hundred machines made and installed by the United Shoe Machinery Company, more are sold outright than are leased. But in order to use their money in making shoes, most shoe manufacturers prefer to lease machines when they can. 
Here is a table of royalties per pair paid by shoe manuficturers who lease machine:

Goodyear welts, men's work

Goodyear welts, women's wor

$\$ 0.05694$

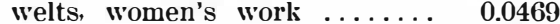

Goodyear turn shoes, women's and misses' 0.005

Men's and women's Mckay shoes ....... 0.01746

Children's McKay sewed shoes . . . . . . 0.01391

The average royalty received, based on the foregoing table, is about two and two thirds cents per pair. In reality IT IS LESS THAN EVEN ONE AND ONE THIRD CENTS A PAIF for most of the shoes worn, because Goodyear welt shoes constitute less than one third the annual production of the United States.

SINCE THE ORGANIZATION OF THE COMI'ANY THE SAVING IN COST OF PRODUCTION OF MEN'S GOODYEAR WELT SHOES EFFECTED BY NEW AND IMPROVED MACHINES AND LOWER ROYALTIES HAS BEEN NEALLY 9 CENTS, OR NEAILY DOUBLE THE TOTAL ROYALTY NOW I'AII).

In return for this trifling royalty, the United Shoe Machinery Company provides American shoe manufacturers with a service that is unrivalcd and unique This service means the assumption of the whole cost of invention, experimental work development, manufacture and depreciation of machines; the cost of ceaseless care of machines to keep them at the highest point of etliciency; the purchase of patents and the cost of administration. President Winslow of the United Shoe Machinery Company has repeatedly said: "IT ASSUMES ITEMS OF EXPENSE AND RISK WHICH, UNDER ANY OTHER SYSTEM YET SUGGESTED, THE SHOE MANUF'ACTURER WOULD BE CONPELLED TO ASSUME HIMSELF, THUS SUBJECTING HIS BUSINESS TO A GREATER MACHINERY COST PER PAIR THAN THE AVERAGE ROYALTY HE NOW PAYS."

Is it any wonder that shoes are so cheap?

KEEPING SHOE MACHINERY UP TO DATE. Nearly all the moder machines to be found in the bottoming department of a shoe factory were either invented or perfected by the United Shoe Machinery Company. Some of them were invented by outside invent ors who were not connected with the United Shoe Machinery Company, but who sold their patents to the United Shoe Machinery Company at a fair price. But most of them were deliberately created by a highly paid staff, to meet the needs of shoe manufacturing. paid staft, to met the needs of she No really good mechen lack of mental or financial suphort. InOM $\$ 500,000$ TO \$900,000 A YEAR ARE SPENT IN IMPROVING OLD MACHINES OR DEVISING NEW MACHINES. If the inventors of the United Shoe Machinery Company are once convinced that some step in the maling of a shoe can be accomplished in a simpler, cheaper, and speedier way, all the resources of the company are placed at their disposal.

It used to be the practice, for example, to tit the parts of a shoe upper to the wooden last by hand. This operation was expensive. It required so much skill and patience that few thought it possible to carry it out by machine. Finally the lasting machine was invented which cared for a part of this operation. It wils still necessary, however, by means of pincers to full the leather over the nicer curves of the last before tacling it in place, and the inventors of the United shoe Machinery company were confronted with the Jroblem of contriving a "pulling over" machine. This 1roblem was solved by them at a tremendous cost. They worked for years and they spent over one million dollar's. When they had at last finished their talsk the f:lmous "Rex pulling over" machine was produced. Despitc all the time, all the money, that was expended on this machine, the shoe manufacturer pays a royalt of onln three cighths of a cent for each pair of shoes made th its means, and this small royalty also covers the use of several other machines used in the pulling over process.

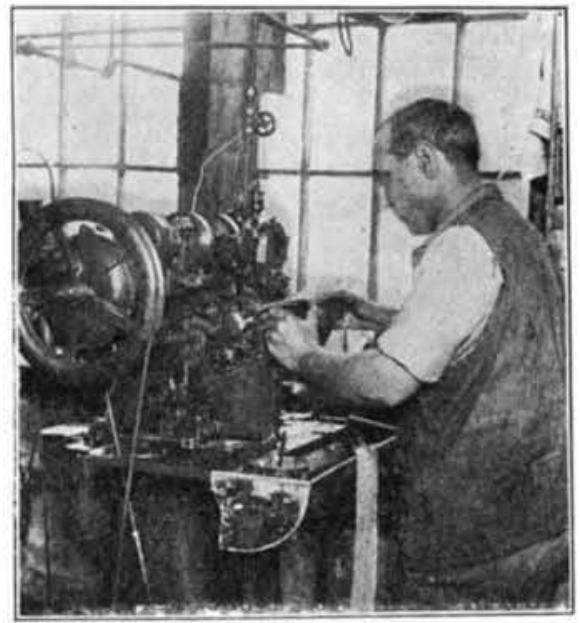

Outsole rapid lockstitch machine of the latest type, used to fasten the outgole with a lockstitch to the welt in making a Goodyear welt shoo.
IT IS THIS POLICY OF CONSTANTLY IMPROVING MACHINERY THAT HAS IEPT THE PRICE OF SHOES DOWN.

\section{SCRAPPING MACHINES.}

Many manufacturers in other industries CANNOT AFFORD TO DISCARD OBSOLETE MACHINES They have invested too much money in them. Their manufacturing costs are often high because their equipment is out of date.

Evcry new invention produced by the United shoe achinery Company means the "scrapping" of hunareds of machines at the United Shoe Machinery Com-

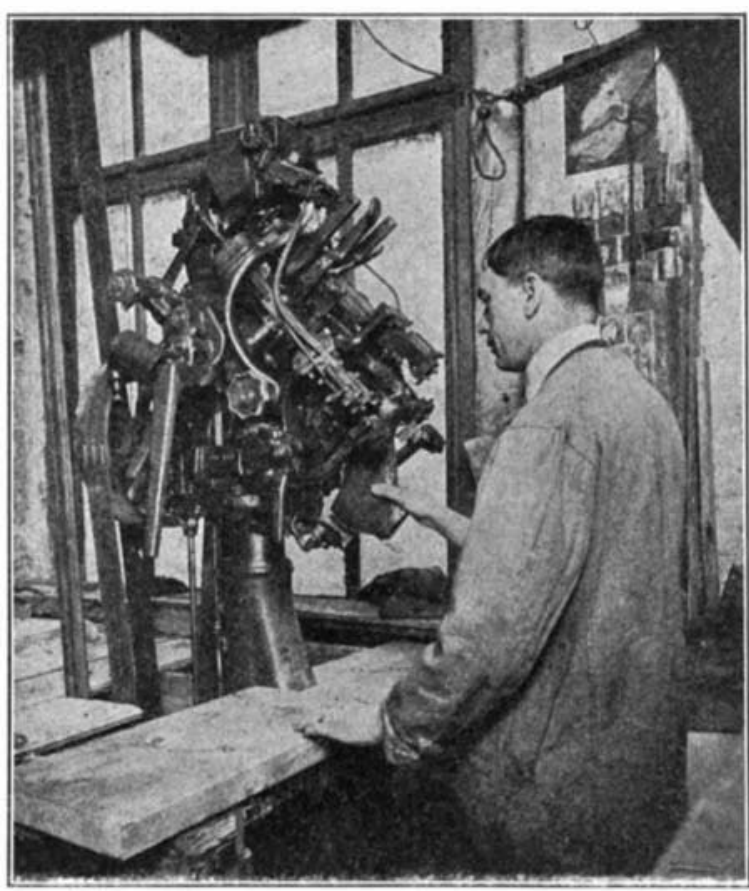

The "Rex" pulling-over machine, which was deve oped at a cost of over $\$ 1,000,000$, and which fits the parts of the shoe upper correctly to the last.

pany's expense. In a single year no less than four thousand machines have been withdrawn to make room for machines embodying the latest improvements. It does not matter if the shoe factory is large or small. All factories receive the latest improved machines. United shoe service is rendered to all on equal terms. THAT IS STILL ANOTHER REASON WHY THERE IS NO SHOE TRUST.

THAT IS WHY EVERY SHOE FACTORY IN THE UNITED STATES, LARGE OR SMALL, ALWAYS HAS AN EQUIPMENT ABSOLUTELY MODERNTHE LAST WORD IN MECHANICAL INGENUITY. THAT IS WHY THE PUBLIC IS ABLE TO BUY SHOES WHICH ARE CONCEDED TO BE THE BEST IN THE WORLD, AT A PRICE TO MEET EVERY PURSE.

\section{THE REPAIR SERVICE.}

Whenever a shoe machine is disabled, the telephone or the telegraph will bring the nearest United Shoe Machinery expert to the shoe factory. Machines ar thus maintained in perfect condition without charge.

Over five hundred repair experts are kept constantly on duty at the beck and call of shoe manufacturers. This expert service means that 100,000 catalogued machine parts must always be kept in stock in the Beverly plant of the United Shoe Machinery Company. Over twenty-one million parts of machines are sent out from the stock room annually to various branches of the United Shoe Machinery Company.

AS A RESUlT OF THIS REPAIR SERVICE, EVERY SHOE MANUFACTURER CAN COUNT ON HIS MACHINERY, AND HENCE ON HIS PRODUCTION. His profits are assured.

THERE IS NO MONOPOLY.

THE UNITED SHOE MACHINERY COMPANY
DOES NOT MANUFACTURE OR CONTROL ALL THE MACHINERY USED IN SHOE MAKING. Its for lace is confined largely to supplying the machines machines for stitching treeing or finishing sloes, and for working sole leather can be supplied by other companies, and which are installed side by side with United shoe machiner

No shoe manufacturer need deal with the United Shoe Machinery Company if he does not choose to do so. He can equip his entire factory with machines which are not made by the United Shoe Machinery Company. If, therefore, the United shoe equipment is to be found in nearly all the 1,200 shoe factories in this country, it must be because it is so highly efficient, and because the manufacturer obtains not merely machines, but SERVICE-a service that enables him to fulfill his contracts to the day and TO SELL SHOES TO THE PUBLIC AT A LOW PRICE AND A SMALL MARGIN OF PROFIT.

The only monopoly which the United Shoe Machinery Company enjoys is the legal monopoly granted by the patent laws of this country to every inventor. Any one who takes out a patent enjoys exactly the same kind of a monopoly. After the expiration of seventeen years-the term for which patents are granted in this country-any one is free to make, use, and sell the invention disclosed in the patent.

The patents on many United shoe machines have expired. Others are free to appropriate the ideas disclosed in them, and others have done so.

The existence and success of the United Shoe MI achinery Company depcnl not only on cffective service, but also on the invention of new shoe machines, which will improve factory methods and wihich will improve the quality of shoes and keep the price doun.

\section{HOW THE SHOE INDUSTRY HAS PROSPERED.} The liberal business policy of the United Shoe Machinery Company has made shoe manufacturing one of the leading industries in this country.

Before 1S99, when the United Shoe Machinery Company was formed, the products of American shoe factories were worth $\$ 25 \$, 900,000$. Ten years later the were worth $\$ 442,600,000$-an increase of seventy per

THE WAGES of those employed in American shoe factories INCREASED FIFTY SIX PER CENT between 1900 and 1909 , or from $\$ 59,176,000$ to $\$ 92,359,000$

Our shoe exports were very small in 1899. The amounted to only $\$ 1,816,538$. In 1912 the value of imported shoes was $\$ 17,380,634$, an increase of more than 850 per cent.

This wonderful growth is due chiefly to the livera business methods and the factory service policy of the Lnited shoe Machinery Company. The wealth of this country has been increased by millions because the United Shoe Machinery Company has systemiltically invented new machinery to lessen the cost of shoe manufacture and to improve the quality of shoes. AS A RESULT, THE SHOE INDUSTRY OF THE UNITE' STATES LEADS THE WORLD.

\section{SHOES ARE NO LONGER LUXURIES.}

Nowadays everybody wears shoes. Yet there was time within memory when shoes were luxuries. A pair of handsewed welt shoes once cost from $\$ 10.00$ to $\$ 16.00$. Only the rich wore them every day. Yet now you pay from $\$ 3.50$ to $\$ 5.00$ for a pair of Goodyear welt shoes, much more comfortable and much better in qualit than the $\$ 10.00$ handsewed shoe your father or you grandfather wore. What is more, you, as an average American, buy three pairs of shoes a year. Shoes are no longer a luxury.

JUDGE FOR YOURSELF HOW MUCH OF ALL THIS IS DUE TO THE POLICY OF THE UNITED SHOE MACHINEIYY COMPANY.

Advertiscment.

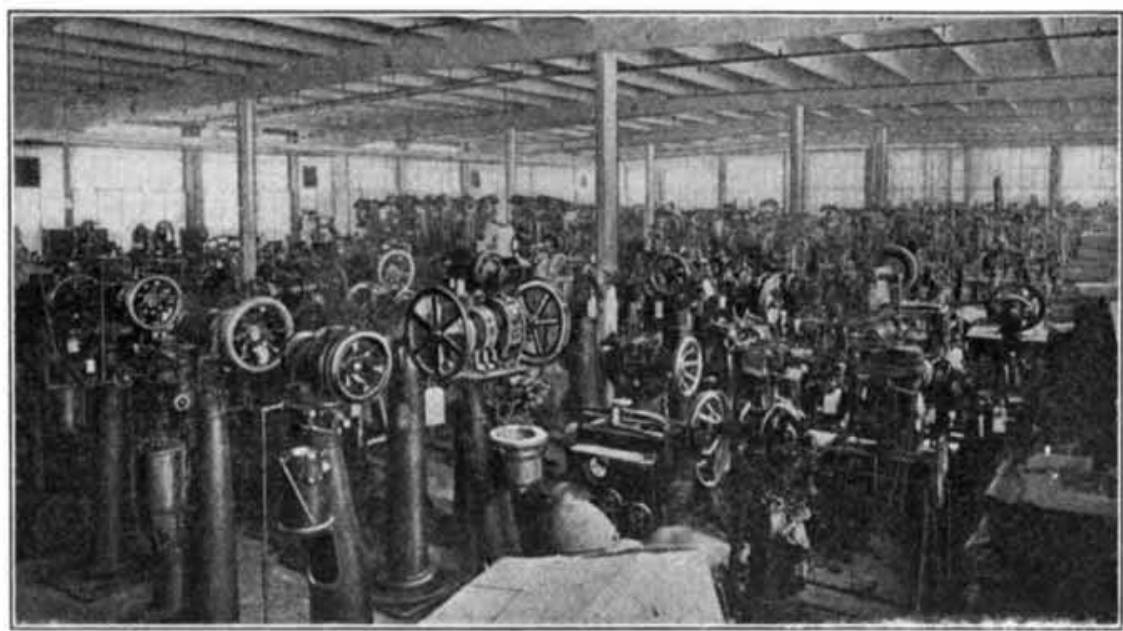

Part of a museum in which two thousand types of shoe machines are preserved, which were once in use, but which have been superseded by bette types. Four thousand machines have been "scrapped" in a year by the United Shoe Machinery Company to make room for more efficient types.

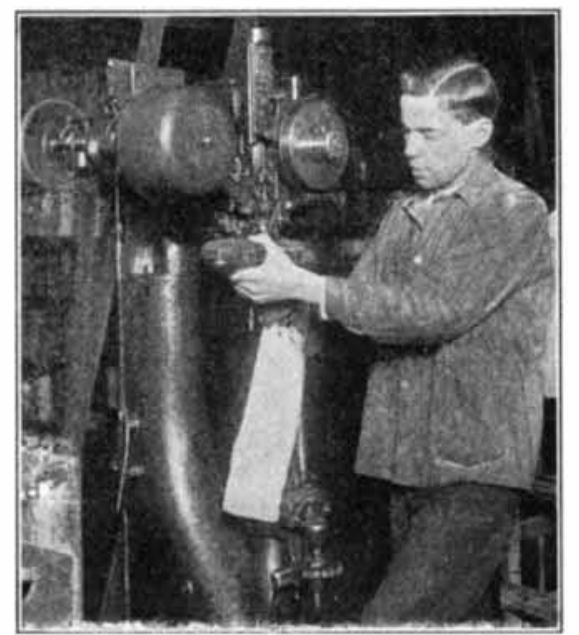

A loose nailing machine. This apparatus is used in fastening the "heel seat" of the shoe preparatory to attaching the heel. 


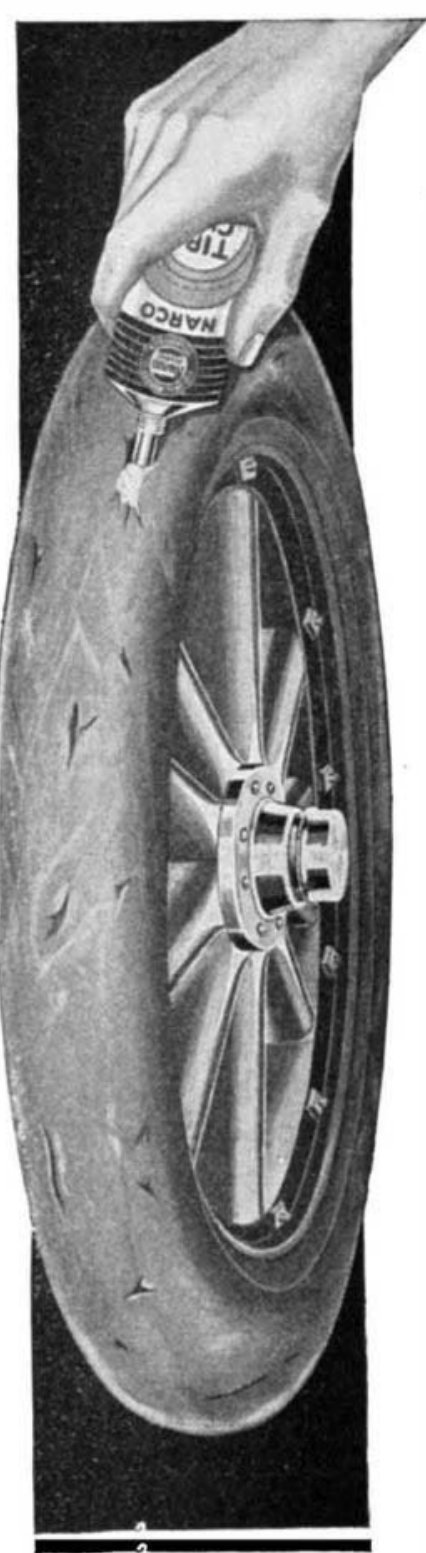

It Heals Tire Cuts

You want to cut out tire repair wastethen you need this self-vulcanizing tire repairer-it does, itself, the extra work you've had to do yourself with the ordinary tire repair mastic. All you have to do is to apply it-it does the rest. Fills the cuts and holes, solidifies quickly and becomes like $a$ part of the tire. No car owner can afford to be without it. Reduce tire expense 30 per cent-use

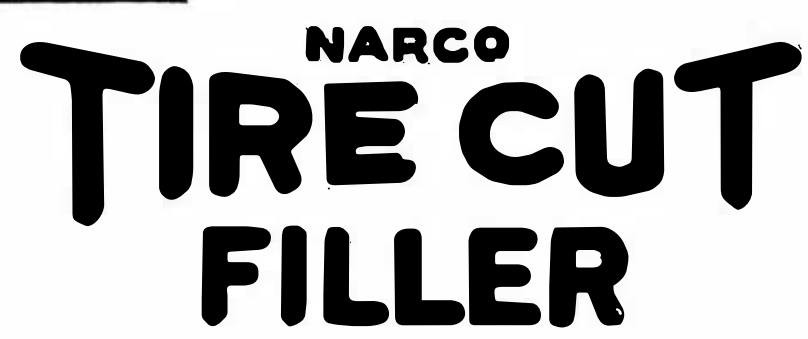

Requires No Kneading

a non-shrinking, rubber compound, heavy in rubber; a combination cement, cut filler and mastic. Refills and unites the torn place in the tire with a permanent plug of rubber more resilient than the tire itself. Welds the loosened tread to the canvas body. Supplied only in patent, collapsible tubes, with tapering spout.

\section{Easy to Use}

All you have to do is to clean the cut thoroughly with gasoline-remove all oil, sand and other foreign matter; insert the tapering spout into the cut and compress the
tube, smooth off the cut filler and the repair is completed. Allow it to heal over night; in the morning it will have become like a part of the tire. Rivetsitself to the walls of the This is the logical manner of tire repair. Every automobile on ther America should make Tire Cut Filler mobile ow his

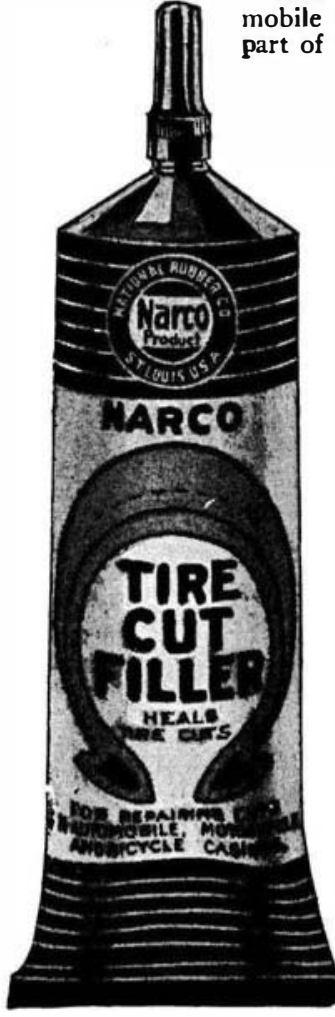

Vors Largo Tube, $\$ 1.00$. $\$ 1.50$ in Canade.
Mones refunded if not satisfied.

On Sale at All Dealers.

If yours can't supply you, we will
Send dealer's name and $\$ 100$;

\section{TIRENEW}

casing of the tires and penetrates down into the inner tabric, protecting it fron! oil, air an decay. Spread it over the surface of your Makes tires look like new.

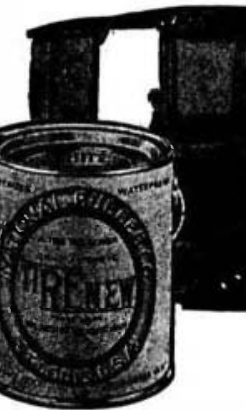

NATIONAL RUBBER COMPANY 4405 PAPIN STREET, ST, LOUIS, MO.
Notes for Inventors

Film for Moving-picture Machine.George W. Bingham of Brooklyn, N. Y., assignor to Bingham-Cameron Company of New York, has patented, No. 1,045,502, a film for moving-picture machines which parent material provided with a series of pictures arranged progressively on the disk, the disk having an opening located in advance of the series of pictures and of sufficient size to permit free passage of the beam of light emanating from the projection apparatus of the machine.

The Patents of the Bath Trust.-The patents owned by the Bath Trust, recently dissolved by order of the supreme Court of the United States, cover principally enameling processes. The major patent of the trust was that granted September 26th, 1899, to James Arrott, Jr. Prior to his invention, the enameling powder was applied by a sieve, attached to a long handle, which was held by the workman with one hand and the sieve made to vibrate by the workman striking the handle with the other hand, thereby sifting the powder over the surface of the iron ware. The instrument was an imperfect one, not easily handled, and by its use the workmen were subjected to intense heat and physical strain. Besides, the flow of the powder was not continuous; it was cast upon the metal in intermittent puffs, causing in many instances an unequal distribution of the powder and producing defective articles, which either had to be thrown away or sold as "seconds." With Arrott's invention The sieve is mechanically vibrated very rapidly, causing, instead of an intermittent flow of the powder as in the hand process, a practically continuous flow. Both hands of the workman may be used to guide and direct the sieve. The advantages of the instrument over the hand process are decided. It is more efficient and more economical. It makes a better article and in less time. There is no waste in "seconds." The workman is relieved to some extent from the fierce heat. Other patents owned by the Bath Trust are those granted to $\mathbf{E}$. Dithridge for a pneumatic sieve, and a patent to William Lindsay for an enameling powder distributor. These are improvements on the Arrott invention.

Protecting Moving Picture Films. - In a patent, No. 1,042,801, Isidor Kitsee, the Philadelphia inventor, suggests that he has found that if a nitrated material is embedded in a carbonate compound, the gases given off by said material are neutralized, the temperature remains stationary and no deterioration is ascertainable. When two films, each inclosed in a receptacle, are subjected to a higher temperature, one film embedded in a carbonate, the other film minus the carbonate, then the film without the carbonate will inflame at a far without the carbonate will inflame at a far
lower temperature than the film embedded in the carbonate, for the reason that the gaseous products of the film embedded in the carbonate are neutralized as soon as they are given off, whereas the gaseous products of the other film tend to raise the therefore, a film used for kinematographis exhibition, he embeds the same in a carbonate of ammonium compound, such for instance as a bi-carbonate of ammonium, sodium, etc., and the container for the storage of films has a lining impregnated with a neutralizing agent for the gases given off by the film.

A Running Support for Flying Machines - Michael A. Parisano of New York city, in a patent, No. 1,049,521, shows a flying machine with trucks pivotally mounted on opposite sides of the main frame so they can swing transversely and having wheels at their opposite ends and springs co nected with the trucks on opposite sides of their pivotal points.

A Convertible Tank Vessel.-A novel construction of convertible freighter and tank vessel is shown in the patent, No. $1,049,490$, to Charles P. M. Jack of New York eity, and includes a ship's hull and a number of removable cylindrical tank which are placed vertically in the hold so therein and adjustable means are provided or connecting the tanks together and to he sides of the hold.

Resignations from the Patent Office Examining Corps. - Notwithstanding the in crease in salary accorded the assistant examiners of the U. S. Patent Office, resignations still continue frequent and during the past year the examining corps has suffered by twenty-four resignations. One of these was a principal examiner. During the same was a principal examiner. During the same ped several members of the corps have Preventing Thumb Sucking.-Jessie Ma Mitchell of Clayton, Miss., has procured a patent, No. $1,048,569$, for a thumb and finger-sucking preventer in which there is a stall fitted on the thumb or finger and a round disk, too large to be inserted in the mouth, is held by the stall on the end of the thumb or finger so the latter eannot be put in the mouth.

Vermin Trap.-A patent, No. 1,048,479, the invention of Joseph Andel of Chicago, Ill., has issued for a vermin trap in which a hollow body has perforated walls and a honeycombed structure within the body or the reception of vermin, and the perorated end walls are controlled by slides which have openings registrable with the openings and movable so the slides can be adjusted to close the wall openings.

A Trap Set by Foot.-Maurice F. Richrdson of Southington, Conn., has secured patent, No. 1,048,586, for a spring trap wich has a pan and a latch to hold the aws open and is provided with lateral foot engaging extensions at the opposite sides of the jaws so that the trap can be set by the eet pressing upon the extensions.

An Improved Beehive.-Francis Danenbaker of Norfolk, Va., a well-known nventor of beehive improvements, as asignor to Robert Johnson, has secured patent No. 1,048,950, for a beehive, the body of which has a ledge for supporting frames or holders and a filling rail for the spaces above the ledge and provides a strip of reated material between the filling rail and the adjacent hive members.

An Electric Rat Trap.-Michal Morawiecki of Pittsburgh, Pa., has secured a patent, No. 1,048,995, for an electric rat trap which has a tilting platform and a pair of electrodes below the normal plane of the lectrodes spaced apart and forming a mouth and operating to control and coperate with the tilting platform.

A Novel Form of Brake Head.-Frederick R. Cornwall of St. Louis, assignor to Chicago Railway Equipment Company, has secured a patent, No. 1,045,261, for a brake head which has an opening of such ize as to permit the introduction of the beam with overlying means for securing the brake beam in order to hold the A Gas-chain Fixture.-Frederick DeWitt Pitcher of Rochester, N. Y., assignor to Welsbach Light Company, in patent No. $1,046,489$ shows a gas-chain fixture in which the gas-supply pipe extends adjacent to the links with its ends extending into ocket members provided on the end links of the chain and connected thereto so that suitable connections may be made with said socket members to communicate with the gas-supply pipe carried by the chain.

Heating Hosiery Electrically. - The General Electric Company as assignor of Frederick M. Vogel of Pittsfield, Mass., as secured patent No. 1,046,514 for a device for drying hosiery in which there is an electrically heated metallic form corresponding generally to the shape of a stock ng and having interchangeable toe portions with a resistance conductor extending into form and the toe portions so that the form may be heated throughout.

Horseshoes by Centrifugal Casting.Reasoning from the dental practice of takng impressions of cavities and then castng by the aid of centrifugal action fillings to the cavity, the writer heard it suggested ecently that some one might invent a ble horseding well fiting and he prepared hoof and then casting in a cenrifugally operating apparatus a shoe to it the hoof. 


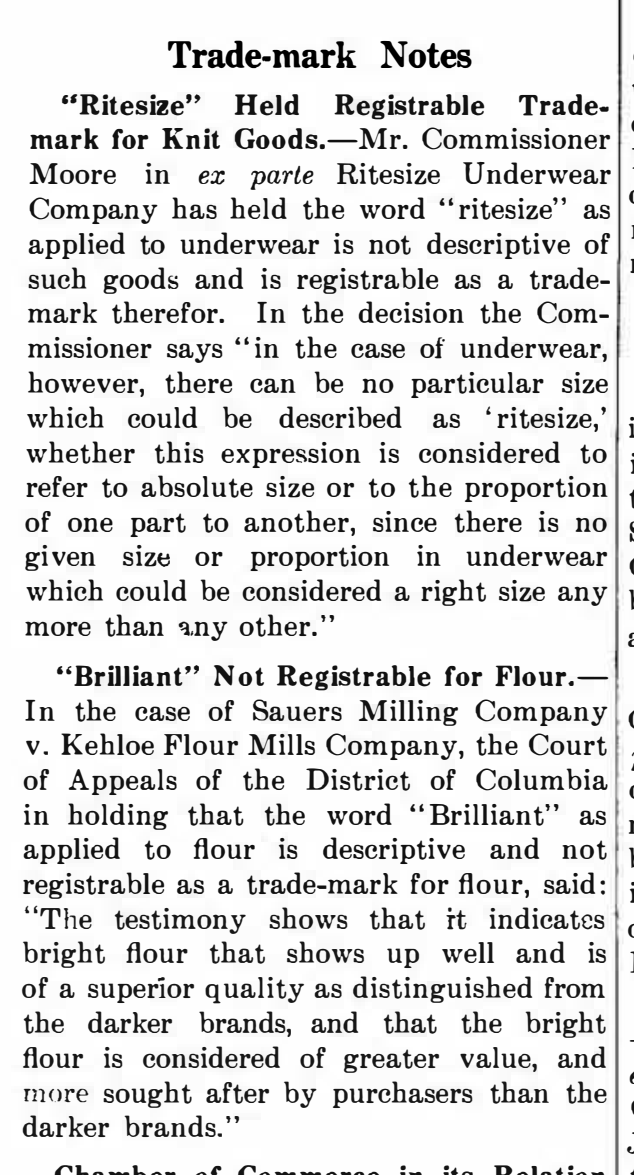

Chamber of Commerce in its Relation to Patents, Trade-marks and Copyrights. -The Chamber of Commerce of the United States of America, with general offices in the Riggs Building at Washing ton, D. C., has appointed its committee on patents, trade-marks and copyright
in several groups located at Rochester N. Y., Detroit, Mich., and Washington, N. Y., Detroit, Mich., and Washington, men and are composed of follows:

Rochester. $N$.

James G. Cutler, Rochester, N. Y., chairma (President Alliance Bank: President Cutle George Eastman (P Mer. N. Y.. Vice-president and Genera
ester. making machinery and nailing machines. George W. Todd (G. W. Todd \& Co.. manu-
facturers of protectographs, Rochester, N. Y. Manager the Pfaudler Company, Rochester N. Y.)
roil. Mich.

James Whittemore, Detroit, Mich., chairman (Patent Attorney, Whittemore, Hulbert Whittemore, Wayne County Savings Bank
Building. Detroit.)

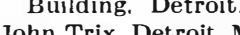

Injector Company.) Henry M. Leland. Detroit, Mich• (Presiden (.adillac Motor Car Company.)
Howard E. Coffin. Detroit. Mich.

dent Hudson Motor Car Company.)

A ger Company.)

Gici. Ellis Spear. Gth and Grant Place, chairmant (Former Commissioner of Patents an W. W'. Kumcuid Matent at ville. Pa

Perry B Turpin. (625 F Street. Washington. D. C. Represents Scientrfic american
alsi) Munn \& Co.? Build Edson. CWashington Loan and Trust nev.)
William G. Henderson. (501 F street. Washington. D. C., patent attorney

It is not the purpose of the Chamber of Commerce to have one general committee. but rather to have each group consider the subjects and reach its conclusion and possibly correspond with the other groups with a view to securing reports from the several groups which instead of being sectional will be in a way national and at the same time give recognition to the different viewpoints of the various sections of the country in which the groups are located.

A Trade-mark Decision.-In deciding the case of ex parte Callahan \& Sons,
First Assistant Commissioner of Patents First Assistant Commissioner of Patents
Billings, in holding that a combination of Billings. in holding that a combination of quotes the answer of the Examiner of Trade-marks, stating that he has correctly patent and the date of filing the applicaman In his statement the Examiner refused transmission, since the mere grant of Trade-marks says: "It is true that a of a patent between the issuance of an $\begin{array}{ll}\text { surname if distinctively displayed is reg- } & \text { original patent and the filing of applica- } \\ \text { istrable; . . . a geographical term and } & \text { tion for reissue thereof does not constitute }\end{array}$ istrable; $\cdot \cdot \cdot$ a geographical term and
descriptive words, even if distinctively tion for reissue, such motion was properly

displayed, are not registrable;" and refers to the decision of the Court of Appeals of the District of Columbia in re Meyer Brothers Coffee and Spice Company a directly ruling that the combination of registrable mark.

\section{Legal Notes}

High-tension Insulator Case--In th interference case of Hewlett v. Steinberger, tension insulators, and referred to in the Scientific American of April 19th, the Court of Appeals of the District of Colum bia has rendered a decision affirming the ward of priority to Steinberger.

Designs. Must Involve Invention.-Mr. Commissioner Moore in the case of $e$ design be patentable it must not only be new and ornamental, but there must have been an exercise of the inventive faculty in
its production, citing the Court of Appeal Adjudication of Cracker Package Patent -In Peters v. Chicago Biscuit Company al. in 200 Fed. Rep., 774, the Distric that the Peters patent, No. 621,974, for method of and means for packing biscuits, crackers and the like, the package consisting of a carton having an interfold lining dus or paraffin paper to exclude the entable novelty in view of the prior art The court refers to the object sought being the approximate exclusion of air, moisture dirt and insects, and to this end being in practice further accomplished by complainant's exclusive licensee, the Nationa Biscuit Company, by the use of an outer sealed wrapper or envelop entirely inclosing ing purposes by the licensee.

Outstanding Licenses Disregarded in Issuing Patents. - In ex parte Dudley, the Commissioner of Patents has decided that Hilereafter, therefore. in issuing either orig-
nal or reissue patents, grantees of interest therein shall not be considered to be other
than assignees because of any outstandin icense or licenses, whether exclusive or not, and the patents shall issue to the same parties The question arose in connection with he issue of a reis sue patent, the Revise Statutes specifically pointing out to whom reissue patents shall be granted, whereas original patents are issued under the genprovisions of the statute which leaves whether the patent shall issue to the inventor or the assignee.

Decision in Interference Case.-AsReasoner has decided that where, in an interference involving an application and a atent, the applicant filed a concession priority to the patentee, judgment set aside upon an allegation that the applicant was deceived as to duration of a license granted by a patentee. It appears from the statement of the case that a party actReasoner an assignment of his right, title nd interest in the patent involved and that Bump was informed that a license had but understood that the hereas it seems the license has not exIntervening Rights in Reissue ApplicaIns.-Assistant Commissioner Tennan the case of Perkins \& Requa v. Week ing an application for a reissue of a patent, motion is brought to dissolve upon the round that intervening rights accrued in vor of the opposing party by the issuance a patent between the date of the original an intervening right. ase of in re Schraubstadter, 26 App. Court, N. D., Illinois, E. D., speaking by the package and contents, which wrappe

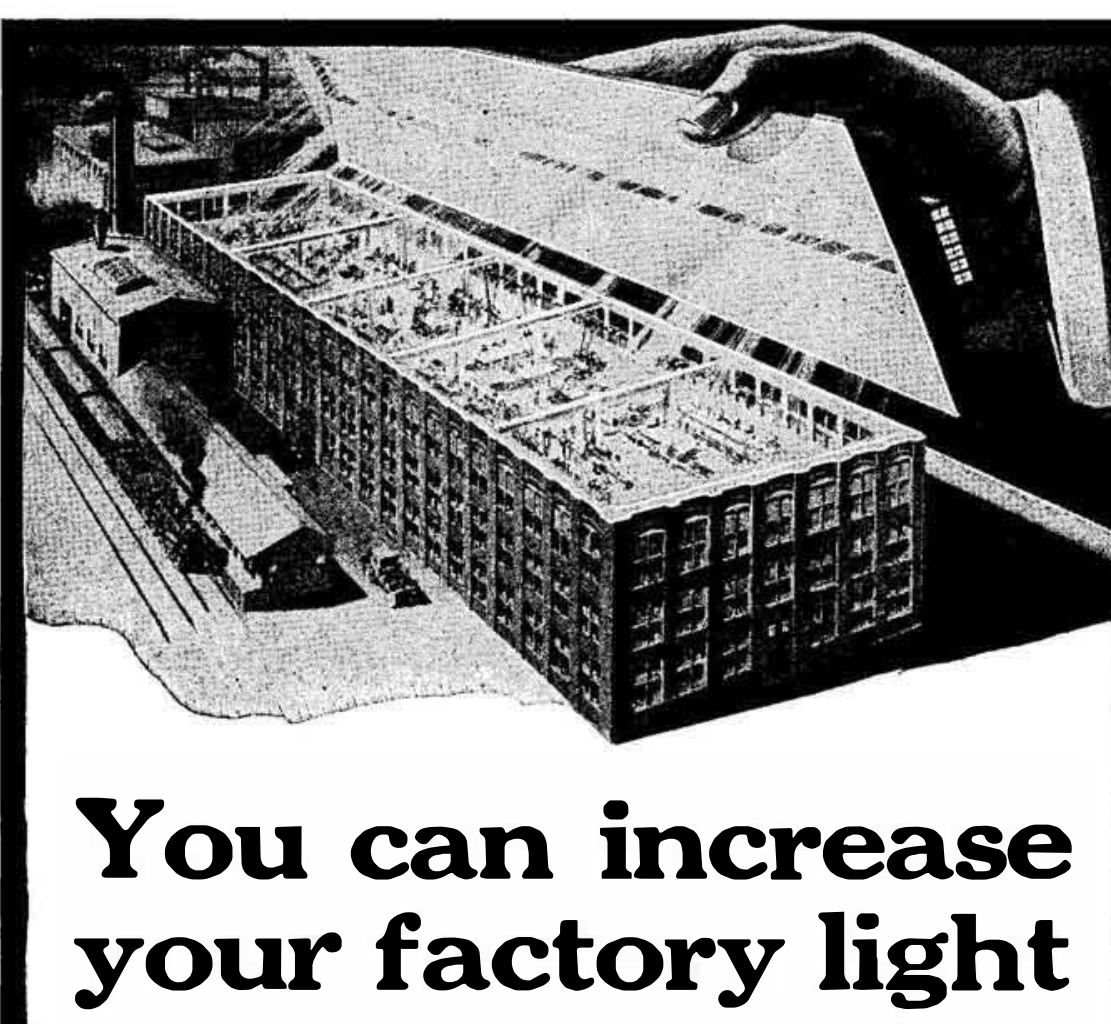

\section{9 to 36 per cent. by not wasting the light you already have}

If your ceilings and walls absorb instead of reflect light, you are wasting light - the artificial light for which you pay good money as well as the daylight which comes in through your windows. Paint your ceilings and walls with

\section{RICE'S MILL WHITE}

It will reflect every ray of natural or artificial light down on to your machinery and into the dark corners of your plant. It will enable you to utilize floor space now useless for fine work. It will lengthen your daylight day at both ends.

RICE'S Mill White will not crack or craze under the jar of machinery. It will not scale or flake like a cold water paint. Its firm, tile-like surface affords no lodgment for germs and odors.

RICE'S Mill White is economical to apply. It flows evenly with no brush marks under a 4 -inch brush. Its g reat covering power and intense body make two coats equal to three of lead and oil. It remains white longer than any other gloss paint.

\section{Suited to Any Surface}

RICE'S Mill White can be applied to wood, concrete, brick-practically any surface over Rice's undercoats. It was the pioneer "Mill White" Paint. It made the reputation of the name "Mill White." The special process by which Rice's Mill White Paint is made cannot be used by any other paint manufacturer.

RICE'S Mill ${ }^{6}$ White is sold direct from our factory in barrels containing sufficient paint to cover 20,000 square feet, one coat. If you have that area or more of ceiling and wall space to cover.

\section{Write for Booklet and Sample Board}

\begin{tabular}{l}
\hline RICE'S GRANOLITH \\
A tough, elastic permanent \\
finish for concrete walls. \\
Becomes a partof the cement \\
to which it is applied. One \\
coat sufficient, unless a gloss \\
is desired. Makes the best \\
possible primer on inside \\
concrete and brick for a \\
second coat of RICE'S Mill \\
White Paint, giving a tile- \\
like, enamel finish at no \\
more expense than lead and \\
oil paint. \\
For Concrete Surfaces \\
\hline
\end{tabular}

Ask for a copy of our booklet, "More Light." It will give you a lot of information about interior factory paints and the names of many prominent users of RICE'S Mill White. Write today.

\section{U. S. Gutta PerchaPaint Company 23 Dodley St., Providence,}

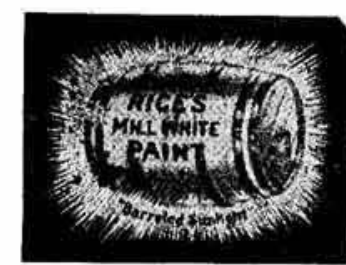



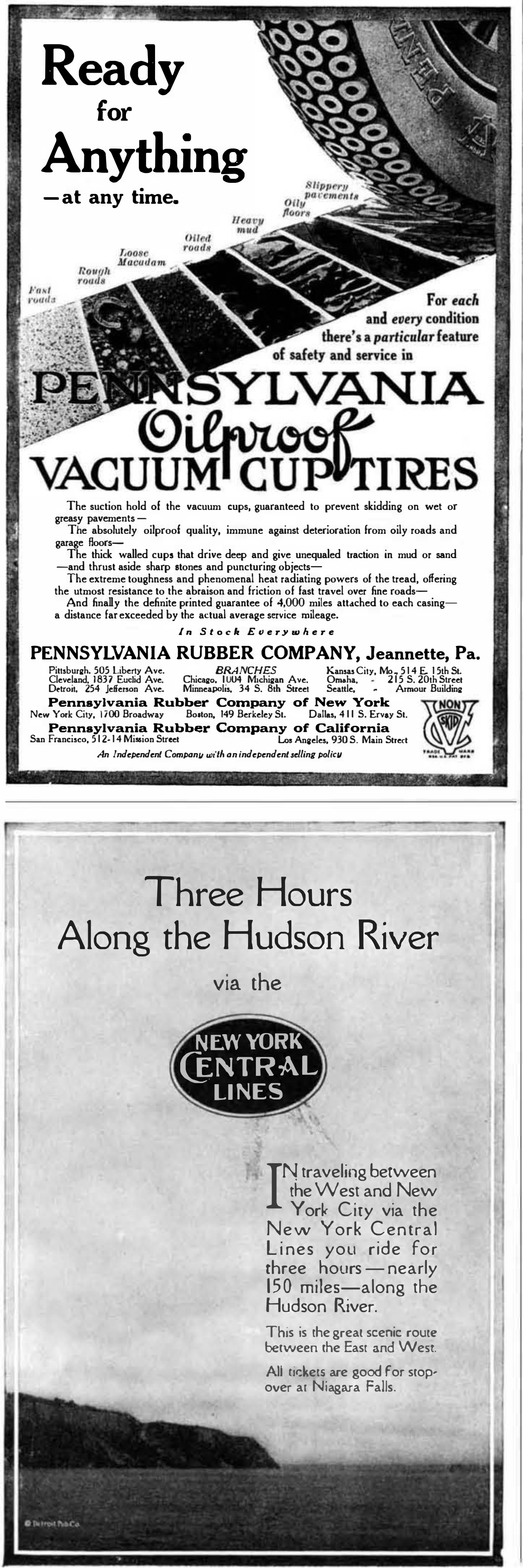

How Patented Inventions Have Increased the National Wealth I $\mathbf{N}$ these days whien great industrial business opportunity, it is grateful to know that there is one open sesame left. During the past spring, after a bill was introduced to restrict the rights of inventors in their inventions, Congress had the opportunity of hearing from the largest corset manufacturer in the United States, the biggest manufacturer of carpet sweepers, the best-known manufacturer of inexmost ad vertised alarm clock in America, the two best-known safety razor manufacturers in the country, the largest manufacturer of cameras and photographic supplies in the world, all the phonograph and talking machine manufacturers in the United States, and most of the manufacturers o the specialties that newspaper and magacine advertising have made household rom . Besides these, Congress also hear the members of the Inventors' Guild, mos of the engineering and electrical and com mercial associations, and, finally, from $\mathbf{M}$ Thomas A. Edison himself.

What these men had to say about the calamities which would follow if the right of inventors were restricted so astonished the Committee on Patents, that the Committee decided not to press this Bill for the present. For all that, it will probably be presented at the coming session, for which reason its objectionable provisions should in

These manufacturers and inventors al told one story: to-day invention, protected by patent, is in all commercial activities the chief, and of ten the only way by whish biness independence may be attained. All this explains why Americans lead the world in invention; why the patents take 40,000 a year and now aggregate nearly $1,100,000$; and why the patents issued by the United States are nearly equal, in annual output and in aggregate amount, to all the patents issued by Great Britain Germany and France combined. Laid en by the United States Patent Office would reach three times around the world. Placed in a pile 10 feet square they would form a mass twice as high as the Washington Monument.

How tremendously patented invention have eontributed to the prosperity of the United States appears from the growth of industriction

In the generation between 1880 and 1910 , the value of our iron and steel manufactures leaped from $\$ 207,000,000$ to $\$ 1$ $377,000,000$, an increase of 566 per cent Between 1860 and 1910 the output of sewing machines grew from less than $\$ 4,500$,000 to over $\$ 28,000,000$, an increase of 522 per cent. Between 1850 and 1910 the production of agricultural implements increased from less than $\$ 21,000,000$ to over $\$ 146,000,000$, an increase of 595 per cent. In the generation from 1880 to 1910 the output of photographic apparatus increas ed from $\$ 142,000$ to nearly $\$ 16,000,000$, a increase of 1,117 per cent.

Coming down to more recent examples of manufactures covered by patents:

In the decade between 1899 and 1909 the output of automobiles leaped from less than $\$ 5,000,000$ to over $\$ 249,000,000$, an increase of 4,880 per cent; the production of wire increased from less than $\$ 9,500,000$ per cent; the output of phonographs from about $\$ 2,000,000$ to nearly $\$ 12,000,000$, growth of 500 per cent; the production of cash registers and calculating machines from about $\$ 5,500,000$ to nearly $\$ 24,000$, of patented food preparations from $\$ 39$,000,000 to $\$ 125,000,000$, a growth of 220 per cent: the production of fountain pen rom a little over $\$ 1,500,000$ to over $\$ 4$, 500,000 , an increase of 200 per cent; the output of photo-engraving from $\$ 4,000,000$ to over $\$ 11,500,000$. an increase of 188 per from less than $\$ 8,000,000$ to over $\$ 22,500$, 000 , an inerease of 181 per centi the pro-
PATENT ATTORNEYS

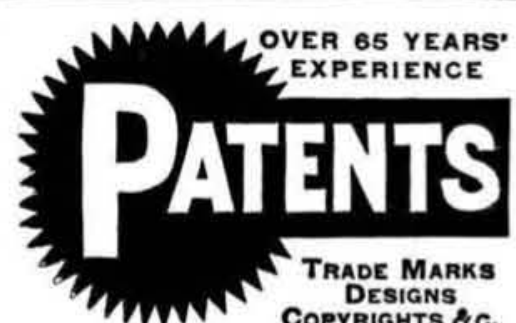
INVENTORS are invited to communicate with
Munn \& Co.. 361 Broadway. New York, o
625 S Street. Washington, D. C. in regard to securing valid patent protection for their Inventions,
Trade-Marks and Copyrights refeistered. Design A A ree Opinion as to the probable patentability
A F

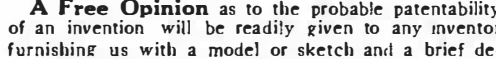

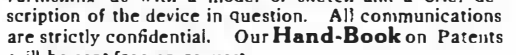

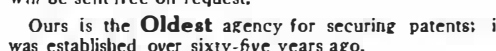
Alp patents secured through us are described
cost to patentece in the Scientific $A$ merican. MUNN \& CO., 361 Broadway, New York Branch Office, 625 F St.. Washington, D.C.

\section{Classified Advertisements}

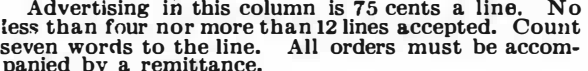
panied by a remittance. All od acs

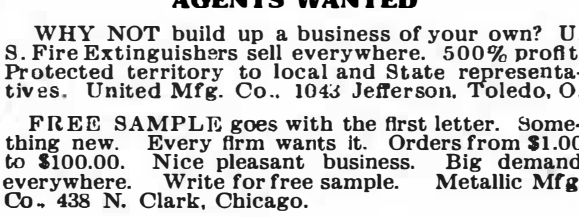
BUSINESS OPPORTUNITIES INVENTORS ! Get rich like Edison and othe he market. We are the inventors' co-operative
factory. Send us your dravings or model (both if

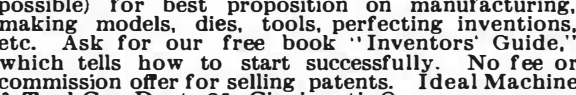
which tells how to start successfully. No fee
ommission offer for selling patents. Ideal Machin
omool Co.. Dept. 25. Cineinnati. O. THE PROCESS OF WEILDING COPPER with
oxyacetylene shall be sold partly or in wholesale to
a concern or a private man. An in quires and offer FOR SALE FOR SALE-Patent, together with Machinery and
supplies, for manutactur ing a thoroughly tested. suc-
cessful domestic \& factory pleating machine Address
Room 202 New Court House Bldg.. New Orleans. La.
MANUF ACTURERS ATTENTION. New Un. MANUF ACTURERS ATTENTION. New Un
,atented Invention for sale. For particulars wrive
oo Charles Eyges, 143 Federal Street. Boston, INSTRUCTION LEARN TO WRITE ADVERTISEMENTS-
Earn 325 to 8100 meekly A We can poritively show
you by mail bow toincrease your salary LINOTYPE INSTRUCTION

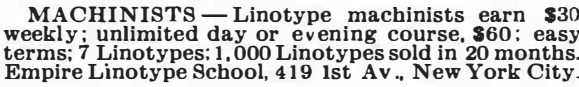
PATENTS FOR SALE WE EXPLOIT OR SELL VALUABLE GER-
ma and Spanish Patents. no advance paymen
asked for. We also arrange for sole selling agencies asked for. We a also arrange for sole selling agencies
in Germany and Spain. Write to H. A. Meinhard.
32 Kronprinzenstrasse, Godesberg. Germany, PATENTS FOR ENGLAND.

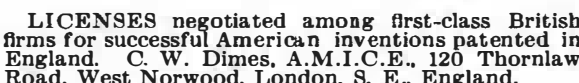
PATTERN LETTERS

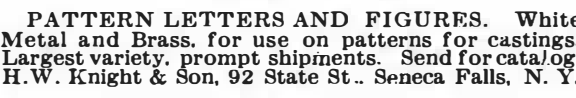
pOST CARDS POST CARDS of Irish Scenery. Irish Life, Irish
Antiquities. Cards of any place in the
Coung Old

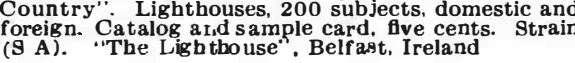
REAL-ESTATE FOR SALE- 5 acres of wooded land with water-
ront on Barker Pond, Me, 20 miles from Portland

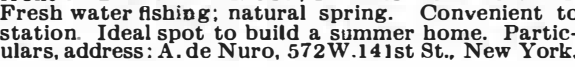
WANTED
FOREMAN, with experience and ability, where
effcient and economical result in auto motor work
is appreciated, desires change. Address Foreman.
Box 773, New York. MISCELLANEOUS SEALED PROPOSALS, endorsed "Proposals for
Two 300 ft. Pteep TOwers, "will be received at the
Bureau of Yards and Docks. Navy Departmen

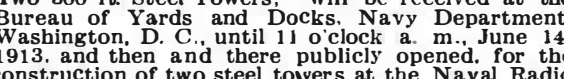

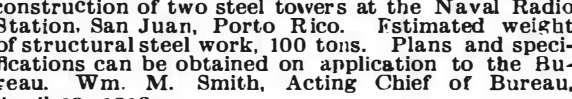
Eeau. Wm.
April 19, 1913.

I N Q U I R I E S Inquiry No. 9.307. W.anted to buy a machine for
honing and stropping safety razor blades on a ccmInquiry No. 9308. Wanted woven glass fabric for
manufacturing purposes in large quantities. The
glass is spun. Inquiry No.9309. Wanted to buy small woven
tubing of small diameter for use over the temple
os spectacles where they go uround the ears. 


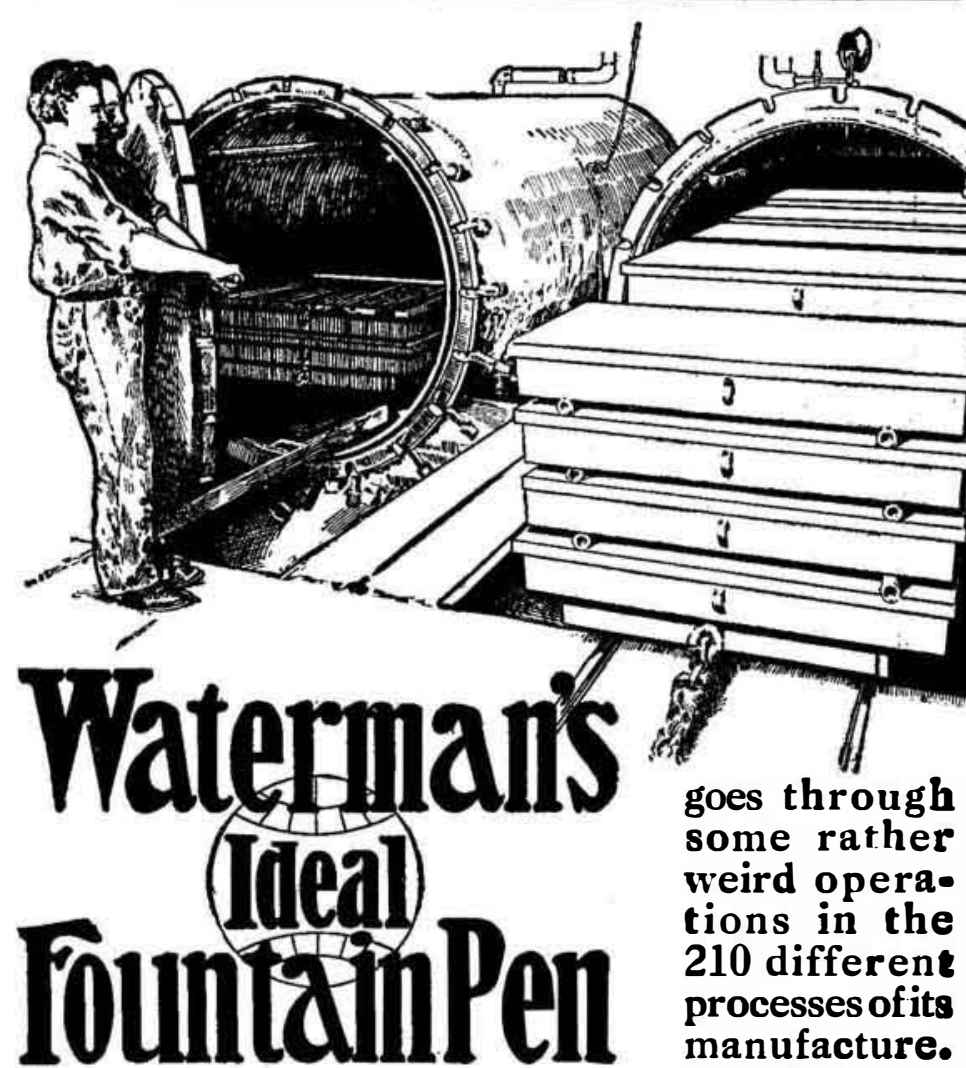

Twin Vulcanizing Ovens

For hours the rubber parts of Waterman's Ideals are locked in these ovens. The enormous heat liquefies, then mixes the rubber and sulphur, giving the basic strength and necessary elasticity, which is found only in Waterman's Ideals. The rubber parts are not blown. They are moulded and hand-turned, hence the accuracy of fit, size, shape and beautiful finish. You never heard of the barrel of Waterman's Ideal breaking or chipping. The more you take the time to learn of the careful scientific manufacture of this pen, the more impressed you will become with its general utility. It's a long but useful journey from the rubber fields of South America to your vest pocket. Illiastrated book on request. You can purchase the size, shape and pen point of Waterman's Ideal Buy the Genuine. Regular, Safety, Self-Filling.

L. E. Waterman Co., 173 Broadway, New York.
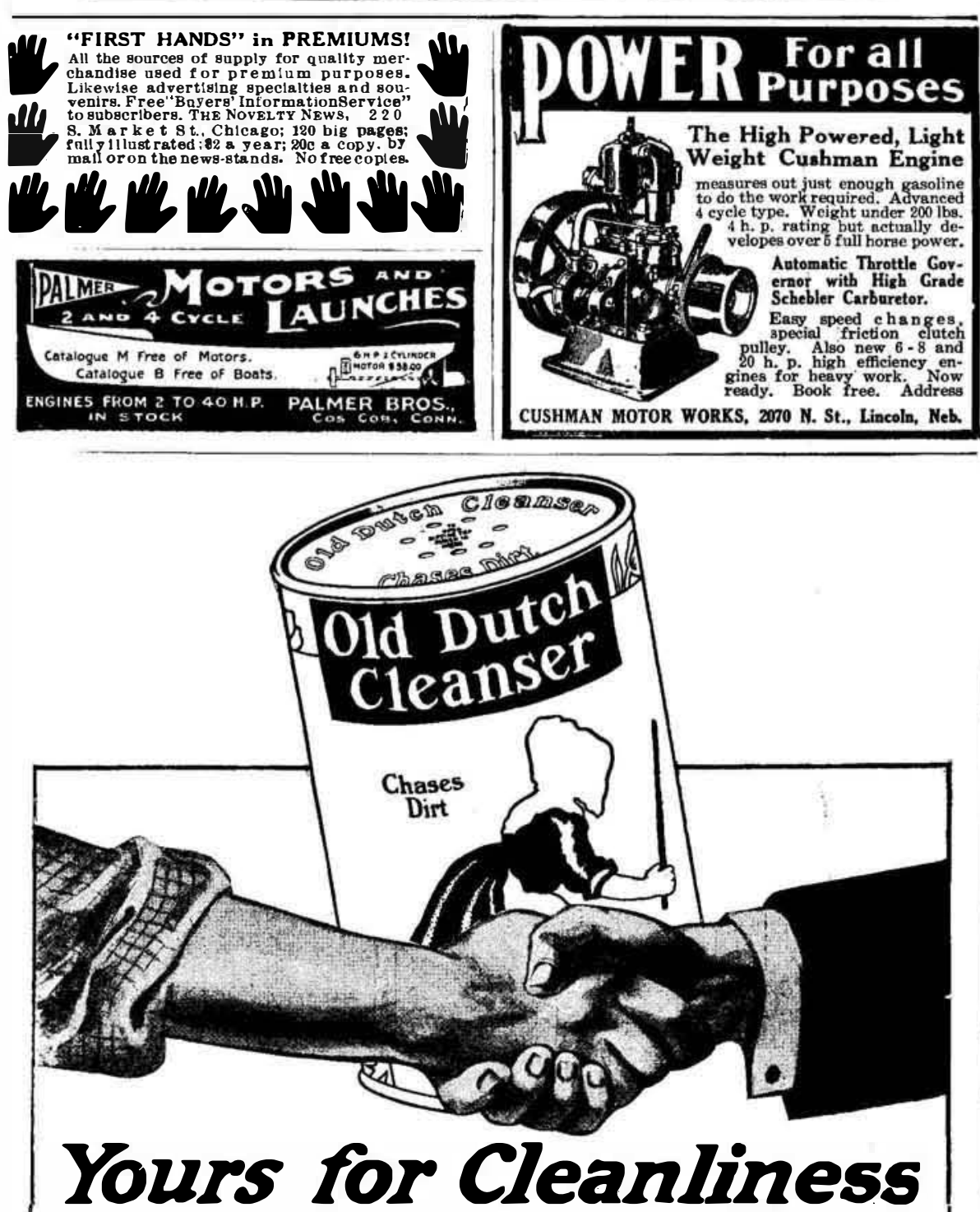

Old Dutch Cleanser is the good friend that brings cleanliness, and lessens the hard work of every cleaning task On lavatories, floors, woodwork, nothing else cleans with so little effort and time.

A little Old Dutch Cleanser will quickly free your hands of siubborn discolorations, dirt and grime.

Many Uses and Full Directions on Large Sifter Can-10 cts. duction of rubber goods from $\$ 52,500,000$ to $\$ 128,500,000$, an increase of 145 per cent; the production of typewriters from an increase of $18 \bar{j}$ per cent; the production of electrical maehinery from $\$ 92,000,000$ to $\$ 221,000,000$, an increase of 140 per cent. The increase in our national wealth produced by commercial inventions is recorde in staggering figures:

In 190.5 our manufactures of iron an steel products aggregated $\$ 2,177,000,000$; our manufactures of textiles amnunted to $\$ 1,387,000,000$; our produstion in the printing and publishing trades was $\$ 597,000,000$ and our manufactures of petroleum producte totaled over $\$ 175,000,000$. During the five years between 1905 and 1910 these manufactures increased, on an average nearly 30 per cent.

During the two generations from 1850 to 1910 the production of cotton manufactures jumped from less than $\$ 62,000,000$ to over $\$ 628,000,000$, an increase of 913 per cent. In the same period the production of woolen manufactures leaped from about $\$ 48,500,000$ to over $\$ 507,010,000$, an increase of 946 per cent. Over the same years the production of silk manufacture increased from less than $\$ 2,000,000$ to nearly $\$ 197,000,000$, an increase of 9,750 per cent. In these three industries alone, each of which owes its very existence to machinery made possible by patented in ventions, the amount of wealth produced in 1910 agreget the enormous sum of nearly $\$ 1,333,000,000$

How widely this enormous wealth is diffused among independent manufacturer and their employees appears from the figure of several representative industries:

Between 1850 and 1910 the capital engaged in the manufacture of agricultura implements grew from $\$ 3,500,000$ to $\$ 256$ 000,000 , affording occupation in 640 individual establishments to nearly $60,000 \mathrm{em}$ ployees, who received in the aggregate nearly $\$ 40,000,000$ annually in wage During the same period the capital en gaged in making sewing machines grew from $\$ 1,500,000$ to $\$ 33,000,000$, affording occupation to 21,000 employees, who re the ann manufacturers engaged in the making of elestrical machinery grew from 76 conelestrical machinery grew from 76 con-
cerns with $\$ 1,500,000$ capital to 1,009 concerns with $\$ 1,500,000$ capital to 1,009 con-
cerns with $\$ 268,000,000$ capital, affording occupation to nearly 106,000 employees, who received in the aggregate about $\$ 70$ 000.000 in wages.

Coming down to more recent examples: What can be more impressive than the growth of the automobile industry? During the decade from 1899 to 1909 the automobile manufactures grew from 57 establishments with $\$ 5,500,000$ capital to 743
establishments with nearly $\$ 174,000,000$ capital. The number of employees, meanwhile, increased from 2,509 to 85,359 . The wages paid to these employees increased during this period from $\$ 1,500,000$ to $\$ 58$, 000,000 .

Between 1899 and 1009 the establishments engaged in wire manufactures increased from 29 to 56 ; their capital grew from $\$ 4,000,000$ to over $\$ 60,000,000$; the number of their employees increased from rose from less than $\$ 1,000,000$ to $\$ 12,500$, 000 .

During the same period the establishments engaged in the manufacture of typewriters increased from 47 to 89 ; their capital grew from less than $\$ 8,500,000$ to ove $\$ 26,000,000$; the number of their employees increased from 4,800 to over 12 , 000 ; their aggregate wages ros

750,000 to nearly $\$ 9,000,000$.

Over the same period the establishment engaged in the manufacture of patented food products increased from 645 to 1,213 their capital grew from $\$ 21,500,000$ to $\$ 64,500,000$; the number of their employees increased from 9,700 to 21,000 ;
their aggregate wages rose from $\$ 4,500,000$ their aggregate wages

to nearly $\$ 13,000,000$

In the same decade the establishments engaged in the manufacture of optical tal grew from $\$ 60,000,000$ to $\$ 104,000,000$; the number of their employees increased from 12,300 to 22,000 ; their aggregate

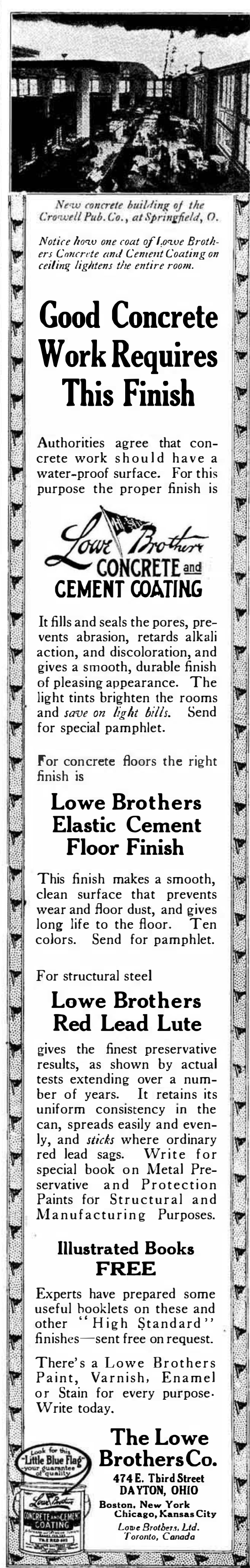




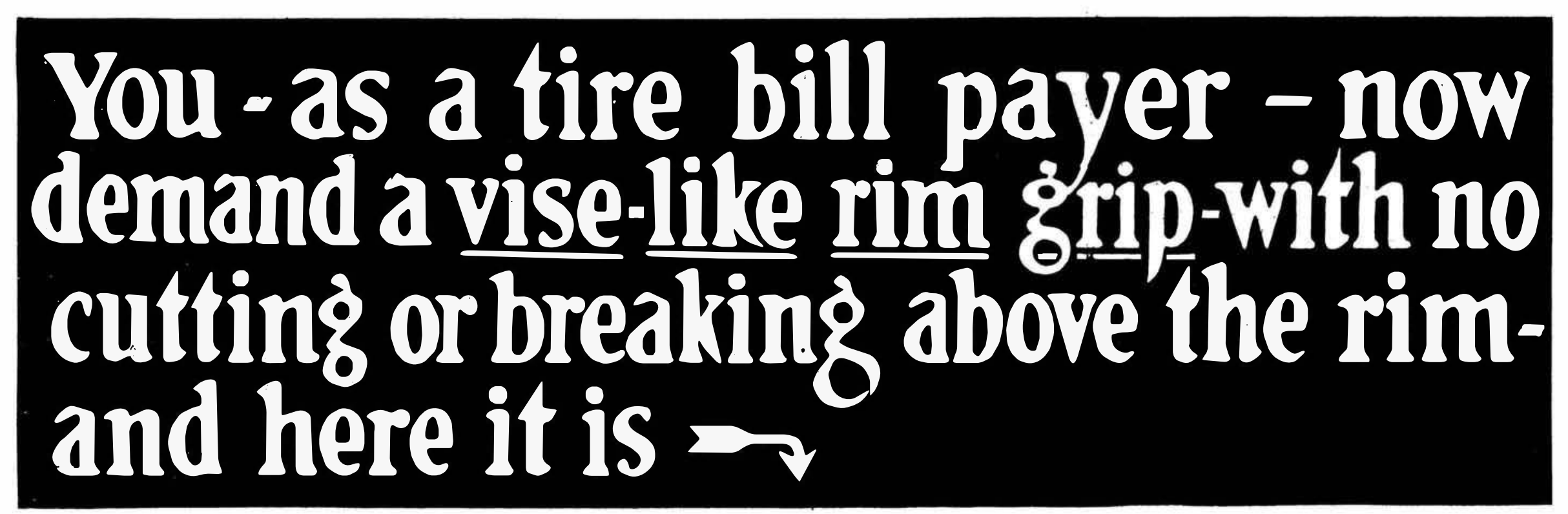

It's the rim as much as the road that wears out your tires.

So we said to our Engineers:

"You must build us a tire with Perfect 3-Point Rim Contact.'

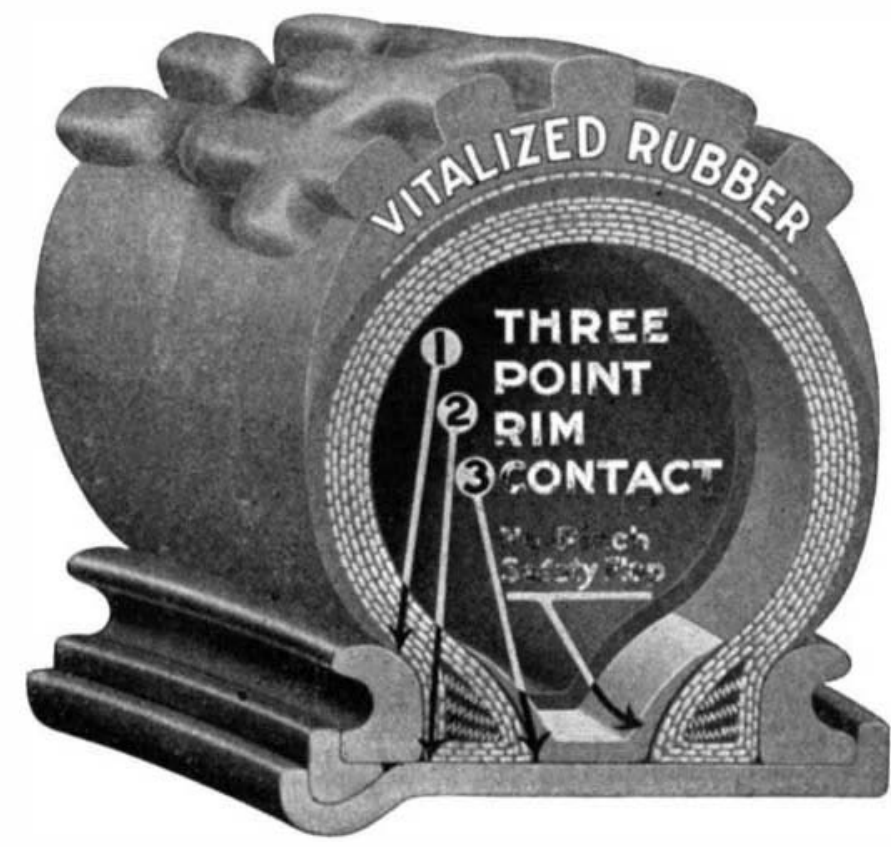

Then we called in our Chemists and said:

"Tire buyers are demanding a tough, flint-like, but resilient tread - a tire made of lusty young rubber -a tire giving the

They did-and they also added the No-Pinch Safety Flap for inner tube protection in utmost mileage at no additional expense.'

And the answer is

\section{Vitalized Rubber}

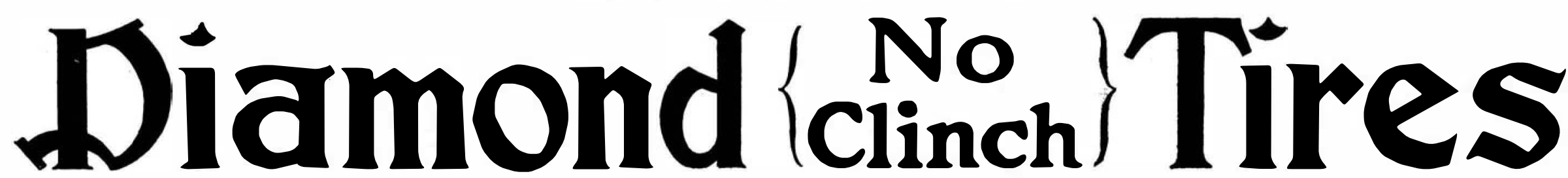

\section{Perfect 3-Point Rim Contact}

Here is a No-Clinch tire that appeals to the hard-headed, shrewd tire buyer - the man who insists on easy riding comfort and a good, liberal mileage.

Each point of rim contact in a tire is a point of support. Where the points of rim contact are not perfect, undue pressure is brought to bear at an unsupported point of the tire.

Then what happens? The result is a terrific strain on the tire that results in rim troubles, breaking above the bead and separation of the tread from the carcass.
All this is overcome in the Diamond No-Clinch because the three-points of rim contact are absolutely mechanically perfect - the annealed steel cable wire bead holds with a vise-like, rim-grip.

Add to this the No-Pinch Safety Flap for inner tube protection, the Vitalized Rubber advantage, the famous Diamond Safety (Squeegee Tread) and you have bought rubber shod mileage that has no equal at any price.
So this time buy Diamond Vitalized Rubber Tires-

\section{5,000 Diamond Dealers always at your Service}

Diamond Safety (squeegee) Tread for Automobiles, Motorcycles, Bicycles 


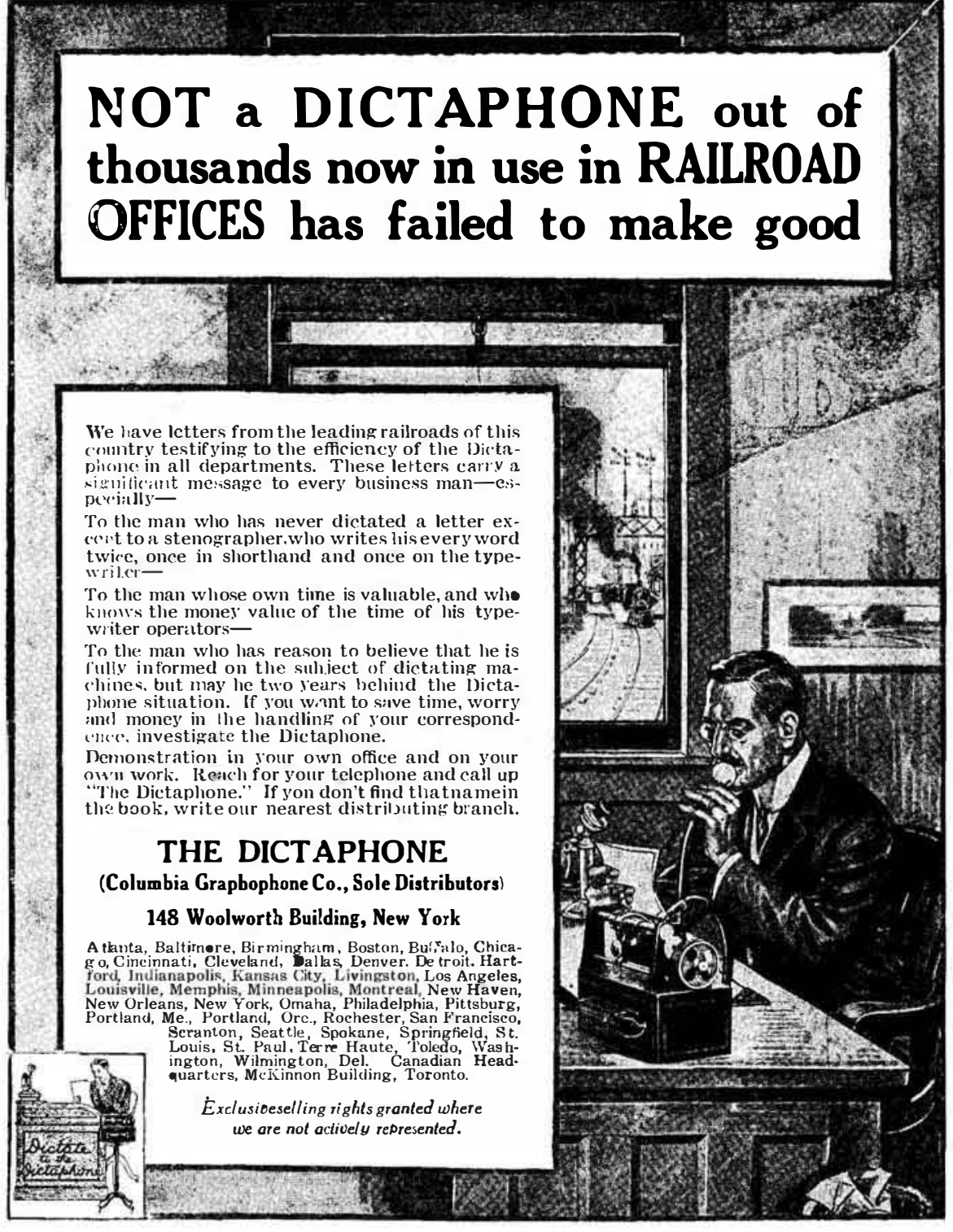

Models and Experimental Work INVENTIONS DEVELOPED
SPECIAL MACHINERY... E. V. BAILLARD CO., 24 Frankfort St., N. Y

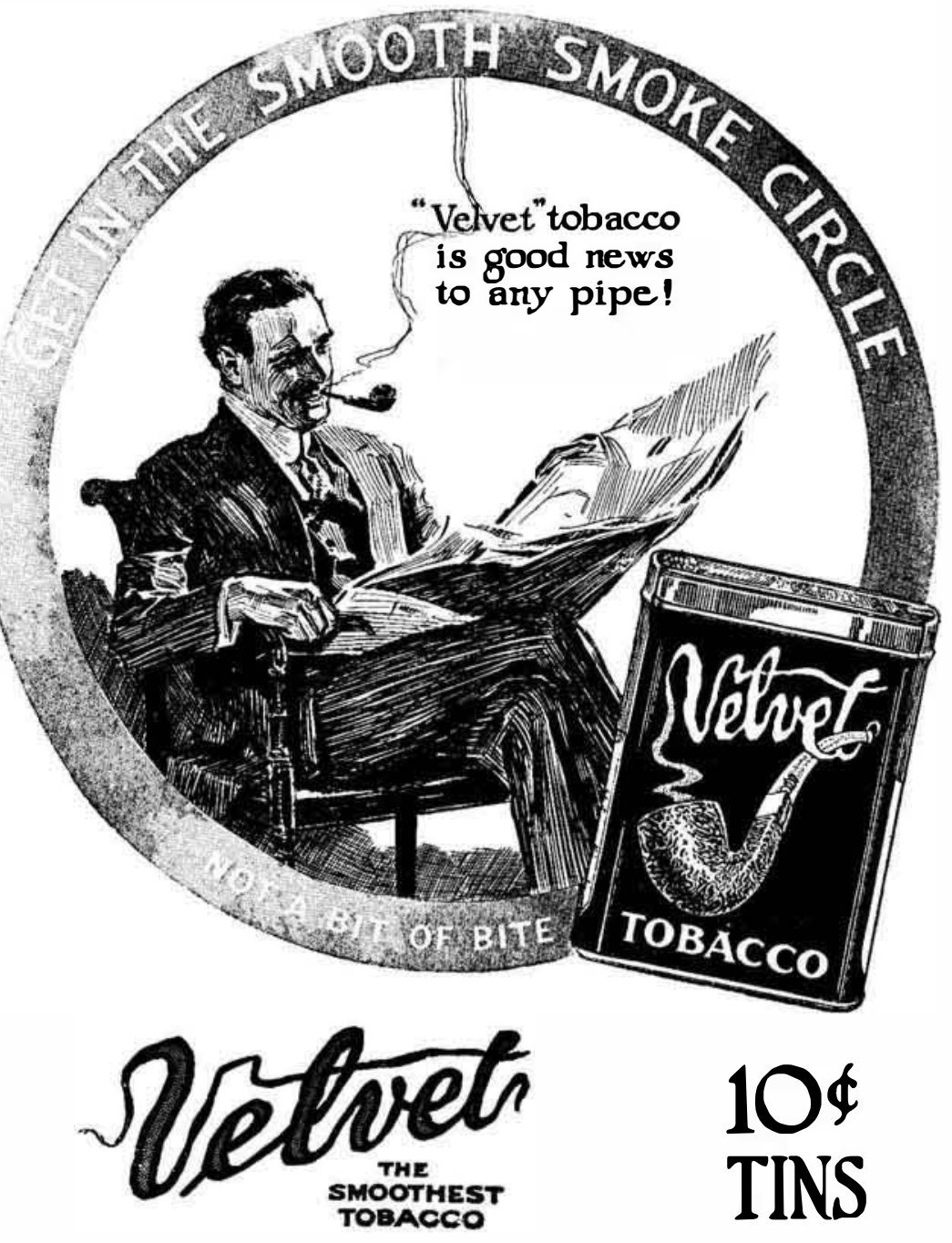

This rich Old Burley has been well aged - a fine flavor and smoke smoothness that will win you!

$$
\text { Lispettrostyper Jodenos. }
$$

wages rose from $\$ 10,000,000$ to $\$ 18,500,000$. Throughout the same period the establishments engaged in the manufacture of capital grew from $\$ 3,000,000$ to $\$ 14,000$, 000; the number of their employees increased from 1,400 to 6,000 ; their aggire gate wages ros e from $\$ 5,750,000$ to $\$ 30$, 000,0100 .

Over the same yours the establishment engaged in the manufacture of fountain pens increased Irom 43 to 65; their capital grew from $\$ 1,0 C 0,000$ to over $\$ 3,000,000$ the number of their employees increased from 742 to $1, \$ 20$; their aggreg

rose from $\$ 500,000$ to $\$ 1,125,000$. ments engaged in the printing and publishing business increased from less than 2:1,000 to nearly 32,000 ; their capital grew from $\$ 333.000,000$ to over $\$ 588,000,000$ the number of their employees increased from 136,000 to 389,000 ; their aggregate wages rose from $\$ 139,000,000$ to $\$ 268,000$, 001 ).

The value of American manufactures attributable directly or indirectly to patented inventions is stupendous. In 1900 amounted to nearly $\$ 21,000,0 x 0,000$-one fifth of all the wealth of the United States; six times the total money in circulation twenty times as much as would be required to pay the national debt; and two hundred produced in the United States. The amount of wages which these industries paid out in 1910 amounted to nearly \$5,$000,000,000$ - more than half as much as the total wealth of the United States in 1850; about two thirds as much as the total money in circulation in 1910; seventeen times the total wages paid in the United States in 1850; and seventy-one times the total amount of money coined in 1910. To invention, more than to any other cause, is due the fifteen-fold increase of wealth in the United States from $\$ 7,135,000,000$ in
18,30 to $\$ 107,104,000,000$ in 1909 . Human comprehension is inadequate to grasp such Gigures.

That wealth produced by patented inventions is more widely distributed among employees and independent manufacturers than wealth produced in any other fashion is strikingly shown in the boot and shoe industry. Between 1900 and 1905 the capital invested in the industry increased rom about $\$ 99,000,000$ to $\$ 122,500,000$ an increase of over 23 per cen t; and during the five years from 1905 to 1910 the capital leaped to over $\$ 197,000,000$, an increase of 61 per cent. Between 1900 and 1910 the commercial ratings of the shoe manufacturers in the United States jumped from less than $\$ 61,000,000$ to nearly $\$ 99,000,000$, 190.5 and 1910 the salaries and wages of all persons employed in shoe factories in the United States leaped from less than $\$ 78$ 000,000 to nearly $\$ 110,000,000$, an increase of 41 per cent. Salaries alone increased 99 per cent, and wages alone increased 34 per cent. During the same period the number of salaried employees expanded from 8,811 the average number of wage earners increased from less than 150,000 to over 185,000, an increase of 23 per cent. From 1900 to 1905 the product of American sho manufacturers increased from less than $\$ 259,000,000$ to over $\$ 320,000,000$, an increase of nearly 24 per cent. During the five years from 1905 to 1910 the output grew to nearly $\$ 443,000,000$, a gain of 38 per cent. Between 1899 and 1910 the value of the exports of boots and shoes jumped rom less than $\$ 2,000,000$ to nearly $\$ 14$ 000,000 , an increase of over 600 per cent According to the last census this prosperity is shared by 50,000 independent retail shoe dealers and 1,343 separate shoe manufacturing establishments, all independent, who employ in the aggregate nearly 200 000 people and have an indi vidual output of from 300 pairs to 25,000 pairs a day. of from 300 pairs to 25,000 pairs a day.
"This industry," states the Massaohusetts Commission on the Cost of Living, in its recent report, "is one of the few great lines of industrial enterprises in the United States in which the trust form of control has not made headway."

These figures all show that, possessed of the control of a valuable invention, the

\section{To the Man with a Ventilating Problem}

You remernber what hot weather meant last summer - stifling room full of bad air, dulled brains, lagging hands, part of your office or factory unusable during the summer months.

You can stop all this at once and forever by installing the

\section{Sturfovint Ventilating Fans}

Even where conditions are wors these fans will keep a room full of fresh pure aur all summer, either forcing out the bad air or blowing in a steady, cool stream from outdoors.

The time to aet is how, before hot weather

Write us giving size and location of room, whether you wish to drive the fan by belt of you have-voltage, cycles, phase, etc.

Our nearest engineer will advise you of the to use. There is no obligation of sepense to you.

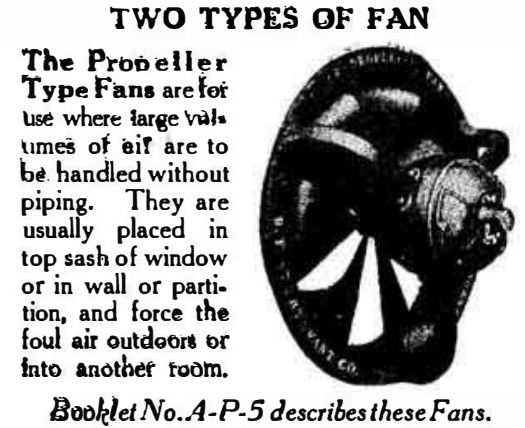

Booklet No.A-P-5 describesthese Fans.

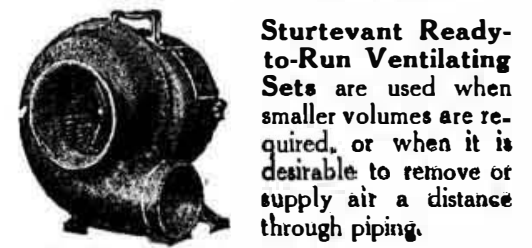

Booklet Na.A-R-5 describes these Sets.

B. F. STURTEVANT CO. Hyde Park Boston, Mass.

American Patent Sales Company We buy, sell ant exploit patentsof o r rocert City
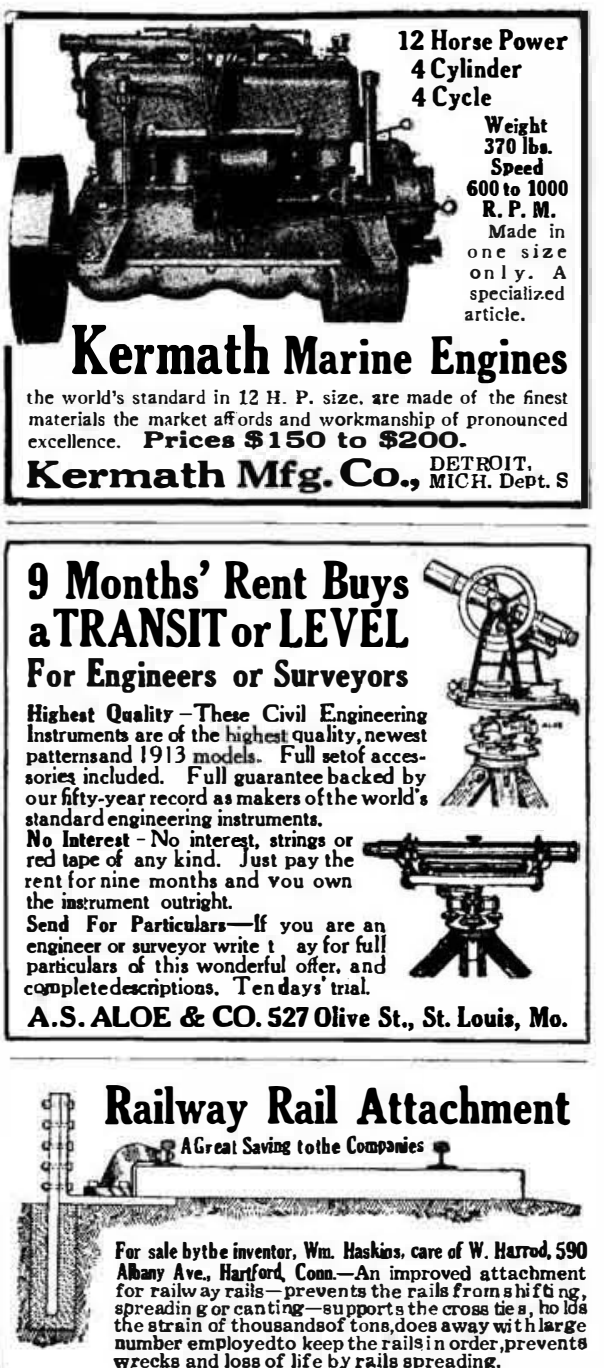


\section{Why Do Bearings and GearsWear Out?}

\section{FIRST, let us analyze friction. Friction is} the resistance or retarding force set up by
two surfaces rubbing against one another Each surface exerts an almost constant pull on the particles making up the other surface. The surface of the two which can
the better withstand this frictional pull will be the surface to remain unworn. The gearing may before the steel. designed as to ing metal should not give way to this pull too easily.

HE cohesive strength of the bearing metal
should approach that of the steel as nearly as possible, just so it keeps under it. Such

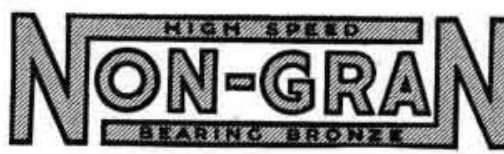

\section{HE interlocked, cohesive, fibrous structure of NON-}

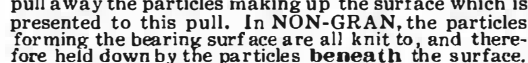

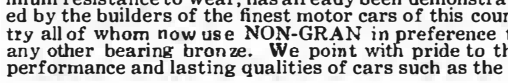

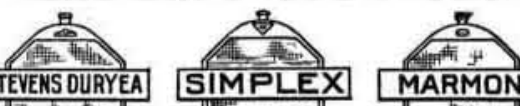

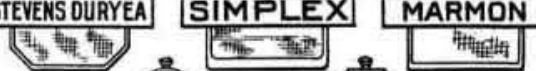
GARFORD SAURER FRICTION is friction, and that metal which best with-
stands friction in motor duty, also best withstands
friction inany other duty dist LET us send you a sample of NON-GRAN so that yo
may examine its famousknit-together structure.

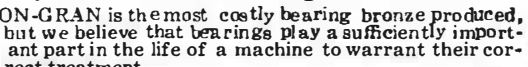

AMERICAN BRONZE CO. 035-1042 CARTON A VE., BERWYN, PENNA.

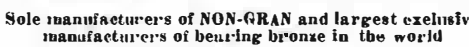

Wear on a Worm or Spur Gear is Brought About
by the Same Forces That Cause Wear in a Bearing. The Combination of Its Wear - Resisting
Qualities and lts Tremendous Strength is Re-
sponsible for the Phenomenal Service Given by sponsible for the Phenomenal
NON.GRAN in These Duties.

\section{Wanted-SpecialWork in Woven or Elec-
trically Welded}

Our equipment is the world for executing in the most goods contracts. Correspondence solicited and an opportunity to figure on your re-
quirements. Send drawings and specificationsQuotations promptly furnished

Pompeiian Bronze Screen Cloth Also an extensive line of other wire cloths Also an extensive line of other
both galvanized and pain

Clinton Eletriallly Welded Fabric for concrele reinforcing
CLINTON WIRE LATH-Est. 1856 Clease address all communicationsto Estimating
CLINTON WIRE CLOTH CO. Extensive Hot Galvanizing Dept. Perforated Metals Dept.

\section{BRISTOL'S RECORDING Pressure Gauges, Vacuum Gauges, Draft Gauges, Differential Pressure Gauges, Thermometers, Pyrometers, Voltmeters, Ammeters, Wattmeters Motion Meters, Tachometers and Time Meters make continuous night aid day records.
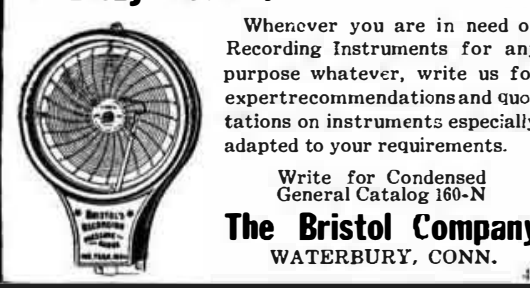 \\ The Bristol Company \\ Company}

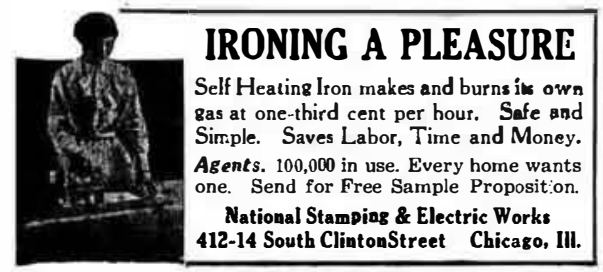

inventor, although backed by a small concern, still has the magic "open sesame" that unlocks the door to the best markets of the world; and that in developing his own business and adding to his own wealth tho inventor adds a hundred-fold to the wealth e community.

Some Old Sewing Machine Patents $\mathbf{I}$ an interesting memorandum pubports of the Department of Commerce, Dr. Darby of the Patent Office tells of the develolment of the sewing machine: how the earliest attempt at sewing by machinery of which there is any authentic record was in 1755 , in which year a
machine was patented in England by machine was patented in England by the stitch was formed by a needle haring two points with an eye at mid-length, which passed completely through the goods in imitation of hand sewing.

Following this came an English pat ent dated July 17th, 1790, granted to Thomas Saint, for a machine that embodied several features employed in the modern sewing machine, namely, an oververtically reciprocating needle, and a feeding device. The needle, notched at its ower end, pushed a loop of thread through a hole previously made by an awl. The loop thus formed was held beneath the goods, and the next loop was known as the "chain stitch."

An Englishman named Duncan in 1804 made a chain-stitch machine that employed two hooked needles, and in 1830 Frenchman named Barthelemy Thimonnier invented a machine which embodied the same principles with the exception that the loop of thread was pulled in stead of pushed through the fabric.

The first American patent for a sewing machine was issued to a man named $L y c$ in 1836. A fire, which occurred that year destroyed all the Patent Office records so that the cons

It is said that in the years 1832 to 183 Walter Hunt of New York city built what was probably the first lock-stitch machine. This was provided with a curved needle (with an eye near the point) mounte on a vibrating arm. A loop was forme beneath the cloth by this thread-carryin eedle, and a shuttle carrying an add tional thread was passed through the loo thus formed, making a lock stitch. Hunt however, did not apply for a latent until after the granting of the Howe

On February 21st, 1\$42, patent No. 2,466 was granted to John Greenough, which was the first United States patent for ewing machine of which there is an existing record. This machine employed wo needles, pulled entirely through the cloth by pincers, and the stitch was formed with two threads, the machine be ing used principally on leather work.

March 4th, 1943, patent No. 2.9\$2 was ranted to B. W. Bean; December $2 \pi$ th, 543, patent No. 3,359 was issued to 6 . H. Corliss; and July 22nd, 1444, patent No. 3,672 was granted to J. Rodger's. In
all of these machines a thread-carrving needle was pulled entirely through th cloth by pincers or clamls, forming whit is linown as a basting or running stitch. Flins How patented his machine tember 10th, 1S46, patent No. 4,750.

The patent No. 6,43!), granted to liachder May Sth, 1S4?, had a spilied, end less belt passed horizontally around tw pulleys. This constituted the tirst prac tical continuous feed.

The Singer patent, No. 8,294, August th, 1551; the A. B. Wilson patent, No 041, June 15th, 1852; and the Wilsor (12) December 19th, 1554, wed. The last named patent included feed device comprising a horizontal bar urnished with a serrated surface, which bar was given an up-and-down motion in eed the goods. This feed, linown as the our-motion feed, is present in pract

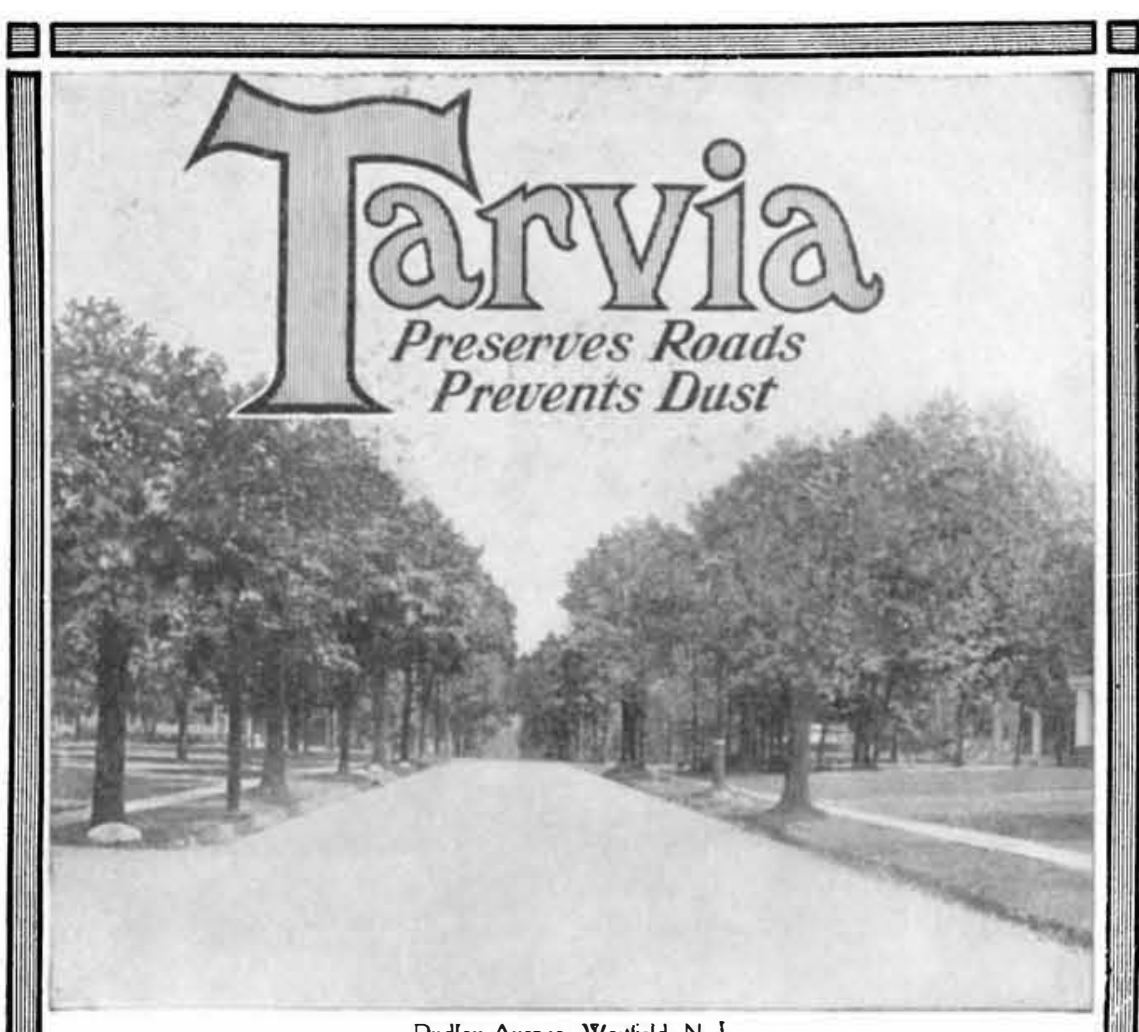

\section{A Tarvia Town}

THERE are many towns in this The roads have been free from country which began with dust and have not been seriously Tarvia years ago and finding it impaired by automobile traffic. successful have extended its use on Tarvia acts as a binder and cements their roadways year by year as a the road surface firmly together in matter of fixed policy. Such a the plastic matrix. Automobiles do town is Westfield, $N$. J., which now a plastic matrix. Automobiles do
has 19 miles of tarviated streets. Mr. A.W. Vars, the town engineer, reports that the "Tarvia B" treat ment on all these streets averaged $13 / 4 \mathrm{c}$. per square yard for the seaso of 1912; compared with the cost of keeping down the dust and maintaining the road surface by any other method, this is a very low figure. not hurt such a surface, but roll it down smoother.

The amount of new stone screenings needed for surface maintenance is greatly reduced by the Tarvia treatment and the road keeps in better condition. The longer the Tarvia treatment is maintained, the less the annual cost.

Booklets on request. BARRETT MANUFACTURING COMPANY

New York Chicago Philadelphia Boston St. Louis Kansas City Cled
Cincinnati Minneapolis Pittsurgh Seatle Corey, Ala.
The Paterson Mfr. Co.. Ltd.-Montreal Toronto Winnipeg Vancouver St.

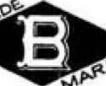

自

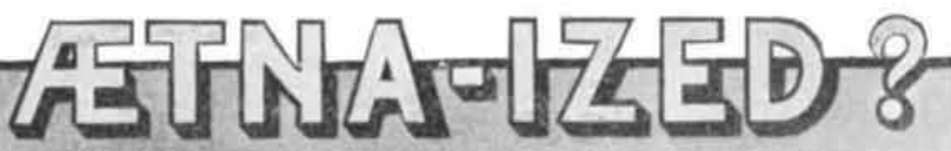

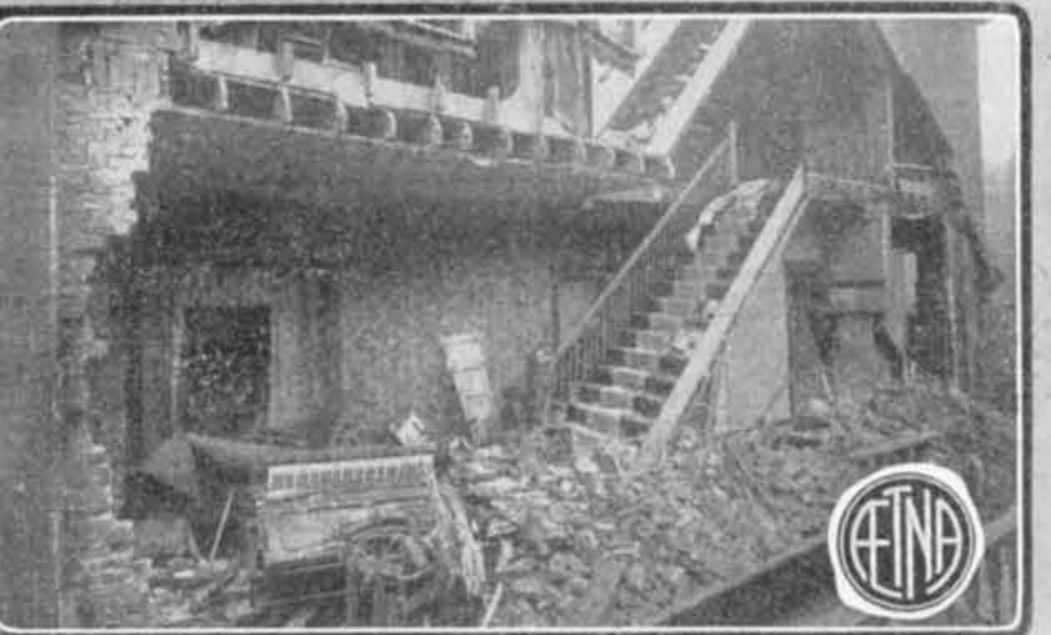

A Wrecked Home

After a gas explosion in the middle Hartford, Conn., cover liberally all of the night in which five persons kinds of accidents. home looked. There are accidents millions in accident claims, and in and in the office-but ten per cent. of all recidents bappen in or about serious as this one, but all of the theeds the protection afforded by ac writing Life, Accident, Health an ent polfies of the FTVA for information about it SEND IN THE COUPON TO-DAX 


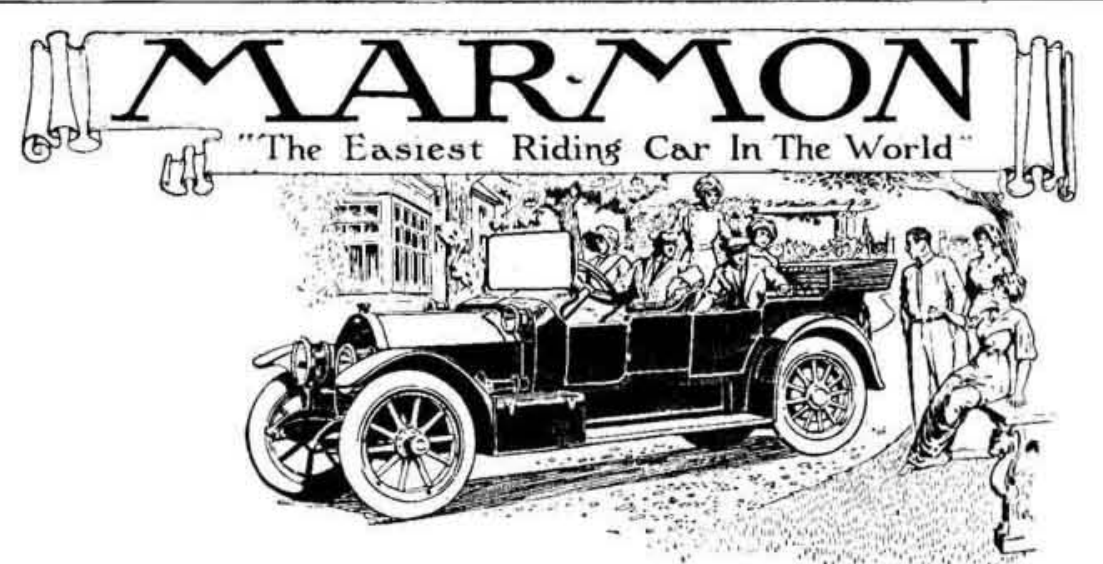

HE superiority of
Marmon design
and construction has been recognized by automobile engineers the world over. The Marmon oiling system, the Marmon axle and various other features have been copied in many of the more costly cars. Doubtless the cheaper cars would also use them, if the materials and workmanship required were not so expensive.

Detailed information on request.

Nordyke \& Marmon Co.

(Established 1851)

Indianapolis. Ind.

Sixty Years of Successful. Mannfacturing.

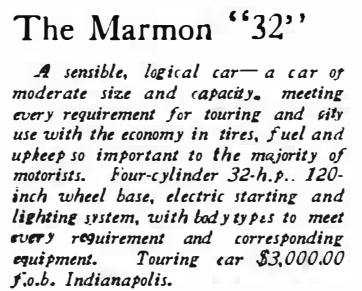

The Marmon " 48 ",

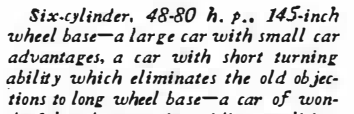
der ful and surpassing riding qualities:
clectric starting and lighting system, clectric starting and lighting system,
with body types to metet tevery require.
ment and corresponding equiprent.
Touring car $\$ 5,000.00 \mathrm{f.0.6}$ Indian

A Fine Little "RED DEVIL" Tool to Own is a combination burner plier, a fat nose and side cutting
plier all in one. $5: 2$ " long, drop forged tool

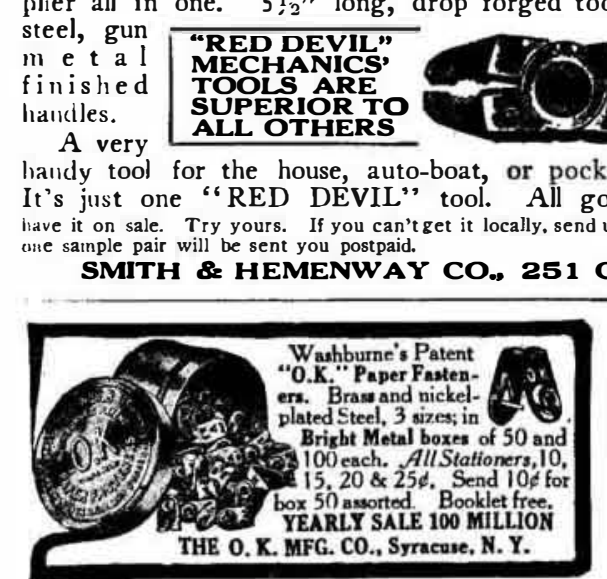
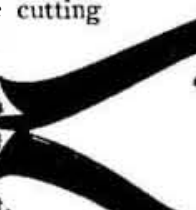

\section{"RED} "Red" DEVIL" Devil", No. 325 ood dealers
us 60 cents and No. to be
Right Right

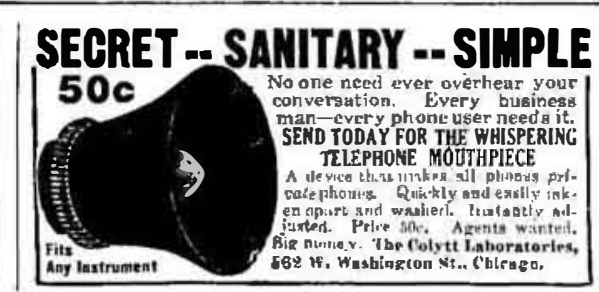

\section{SAFETY IN TRAVEL}

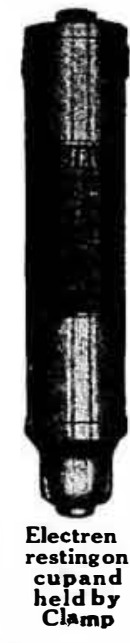

An achievement never yet reached. Even the planet may some
time be in a collision-If so, and if there should be afire, we do not time be in a collision-If so, and if there should be afire, we do no for incipient fires NOTHING EQUALS ELECTRENE, and ELECTRENE in your trunk-

ELECTRENE in your automobile or boat-

or more valuable lives and will always give save valuable property

ELECTRENE_an Improved Extinguisher

Approved by U. S. Board of Steamboat Inspectors

Notably good for electrical and gasoline fires.

motable institu-

tions and firms in preference dealer. If he doesn't carry Electrene, send us $\$ 7.00$

for a one quart Electrene.

Simple-Handy-Reliable.

ELECTRENE COMPANY

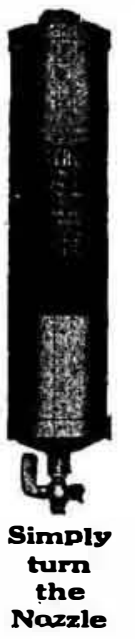

divided into two classes, one including those for household or domestic use and the other special machines, such for instance as the Mckay shoe sewing ma-

The Big Aeroplane and Transatlantic Flight

T HE offer of a prize of $\$ 50,000$ for a 1 fiight across the Atlantic Ocean in seventy-two hours, which was made realready brought forth about a dozen welllinown constructors and pilots who are preparing machines for this flight.

Something over a year ago, we published in the Scientific American a ver complete article on the transatlantic crossing by aeroplanes, together with a fulllage illustration of a proposed biplane with five 50 horse-power Gnome motors by which A riator-Mariner James V. Martin proposed to make the long flight. Recently a hydro-aeroplane has been con-
structed in England having three 50 horse-power Gnome motors arranged in somewhat the same manner as suggested by Mr. Martin, and having two fioats in the shape of boats beneath the machine in ried. This machine, although only about half the size of the one designed by the American aviator, is built along the lines suggested by him. His idea was that after the machine was once in the air, one of the motors could be disconnected and the machine would run on the other four motors, or two hundred horse-power. became lighter, another motor could be cut out, and perhaps before the end of the voyage the machine would fly on but two motors, thereby making a great saving in fuel.

In order to cover the 1,500 miles from Newfoundland to I reland, a speed of sixty miles an hour must be maintained for continuously on a machine large enough to carry sufficient fuel to make the flight without a stop, a motor of from 150 to 200 horse-power is necessary. A six-cylinder, water-cooled motor, such as is use on the German Zeppelin dirigibles, is the

most economical and reliable motor fo this purpose. Such a motor will consum only about one third of a pint of gasoline per horse-power hour, and very much less oil than will an air-cooled, revolving-cy inder motor like the Gnome. A 50-hou continuous run is nothing out of the ordinary for one of these airship motors; but in order to be absolutely certain of malsing the crossing, it would be well to have The main point to be taken into consideration in the design of a transatlantic aeroplane is the reduction as far as possible of the head resistance. On this hangs the probability of crossing at the maximum speed and the minimum expenditure of fuel (that is, weight). As to the machine itself, this can hardly be con. structed to weigh less than fifteen pounds to the horse-power. With fuel, powerful motors, men and supplies added, this
weight may increase to as much as thirty or forty pounds per horse-power, which would mean a huge machine having 1,200 to 1,500 square feet of surface and weighing complete between three and four tons. At once the question will be aslied, built and flown successfully.

The answer is, that some six months ago an aero-yacht biplane was constructed chine weighed complete with its live load chine weighed complete with its live load over 6,000 pounds, and, propelled by a 200 horse-power motor, showed a speed of 68 was fitted beneath the liplane, excellent speed was made with six or eight people. With the live load put into fuel, this machine would be capable of making perhaps one third of the distance across the Atlantic.

Another huge hydro-aeroplane that has recently been constructed, and that was

\section{The Safe Garage} Built as strong as a steel sky-scraper

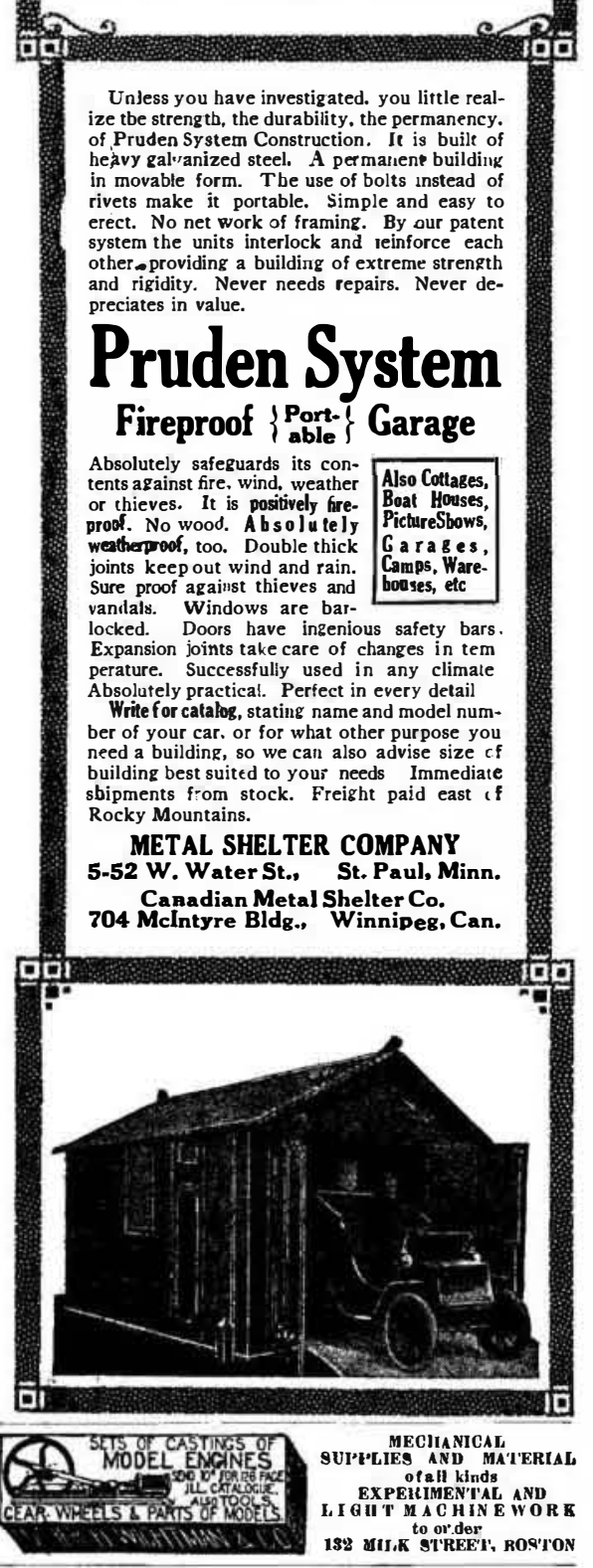

\$92.50-Our Price for 30 Days!

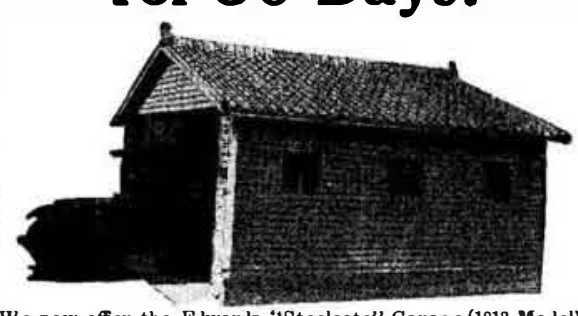

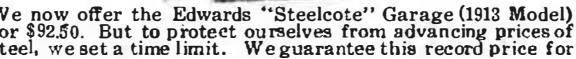
only. Edwards Fireproof Garage

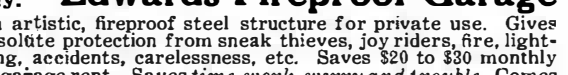

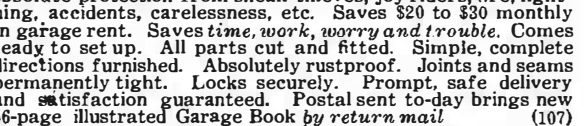
The illustrated Garage Book by return mail co (10)
THE EDWARDS MANUF ACTURING co.
C.692 Eggleston Ave.
Cincinnati, Ohi

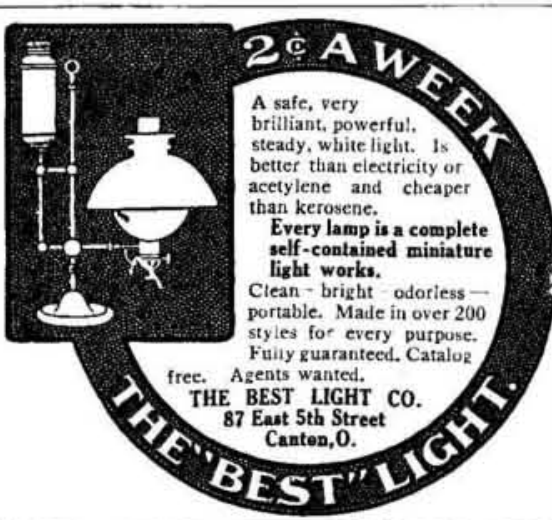

Rider Agents Wanted

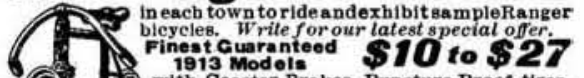
(1) 1. 1)

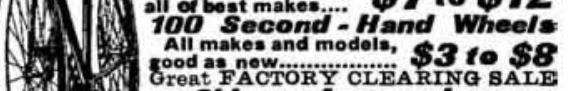

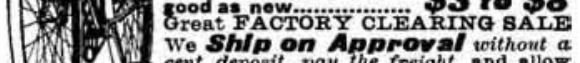

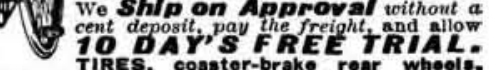

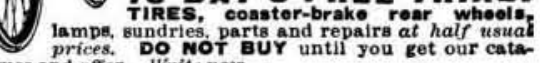
logues and offer iV irite noto. 


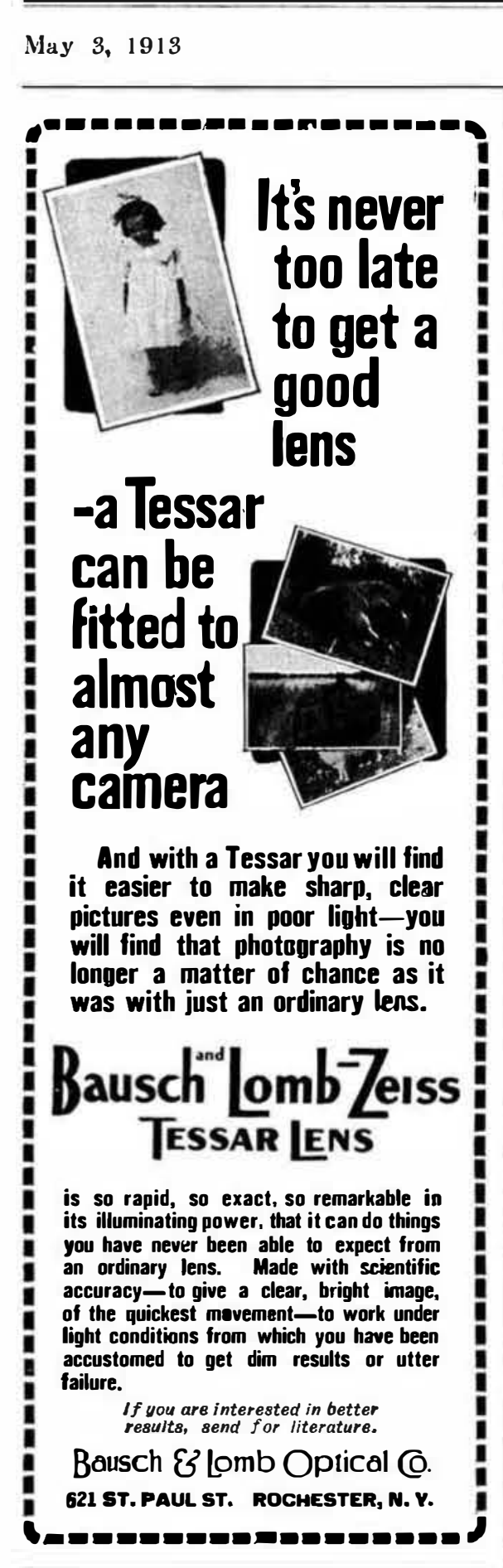

\section{Which Are You}

- an investor or a speculator?

I It you are a speculator, we have if you are an investor; if you seek a than an indefinite or problematical in come some time in the uncertain future. we would like to send you our new Real Edre Sechidy Compen

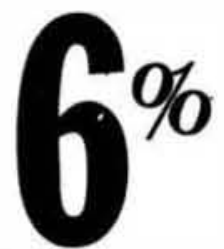

\section{Gold Mortgage Bonds}

Denominations : \$100, $\$ 500, \$ 1000$

Protected by Trust Mortgage Interest Payable Semi-Antfally

I These bonds are thoroughly secured dollars' worth of high-class, improved, income-producing city property - located the most valuable and most productiveareaofits size in the world.

G The Bonds appeal only to conservative

Complete information will be sent free for Booklet 23 .

NEW YORK REAL ESTATE SECURITY CO.

Assets Over \$1 7.000.000

BROADWAY NEW YORK ing of two sets of biplanes mounted ujo single hydroplane hull, in which there are two 230 horse-power, six-cylinder mopropeller. This huge machine has syread of nearly eighty feet and weigh parable in size and weight to the saxim machine which was built and flown in England in 1891, and which, had it bee mounted upon floats and tried on the ivachief helper, Henry A. House, to do, would have undoubtedly flown without mishap uve was when it ripped up the holding-dow guard rail of the track upon which it wa tried. This machine, by the way, had 363 horse-power, consisting of a steam engine Whible propellers.

While neither of these two large hydrojust mentioned has been de(the with all the experience obtained with dirigible balloons and aerollanes having streamline bodies, it will be possible to design a machine having very much les head resistance than the usual weightcarrying

Obtaining Power from a Testing Plant

t

uring the tested from page 408.)

The tractors are belt connected

shunt-wound generators, running in parall. This makes a very flexible outfit, s each engine load can be regulated by the rheostat of its generator and the load an be increased from small to full load as the engine warms up and works into the best condition. The fuel and water it an easy matter to lieep the engine tanks filled. Each fuel pipe is provided with an individual meter. Suitable staclis ar dhe blocks under

The changing of a tested tractor is matter of five minutes. Fuel and water lipes are removed from tanlis, bloclis linocked loose and the stack raised. The tractor is then run ahead and the belt removed. The operations are reversed when running a newly constructed ma-

are shunt-wound, directcurrent 250-rolt machines. This type i used because it is automatic, to an ex tent, in regulation. If there is any trouble motor, thus often saving the trouble starting all engine because of dirty plugs or some minor trouble. Also in case i adjusted to carry a very small load. Further, engines of $30,40,60$ and 50 Further, engines of $30,40,60$ and so horse-power are often being tested at one time. This condition would be quite diffidynamo.

All wires are run under the floor in conduits from

A balance set is used, as the plant furishes current for both light and power. The balance set is started by means of two switches and a rheostat, the field be ing permanently connected to the busbars. The balance set consists of two 30-kilowatt generators. The shafts are fiexibly connected, and there has been no mechanical trouble whatever. The overload capacity is large, as a number of large motors have been constructed that rin with 220-volt field and 110 to 220-volt almature current.

The power generated is used for running a machine shop, two foundries and various machines and lights about the plant. Two 20 and wo 10-ton cranes, two 50 horse-power air compressors and large heating fan motors are some of the he: ier motor loads. These machines and lights, of course, cause a great variation in the load, frequently varying it 100 per cent within a short time.

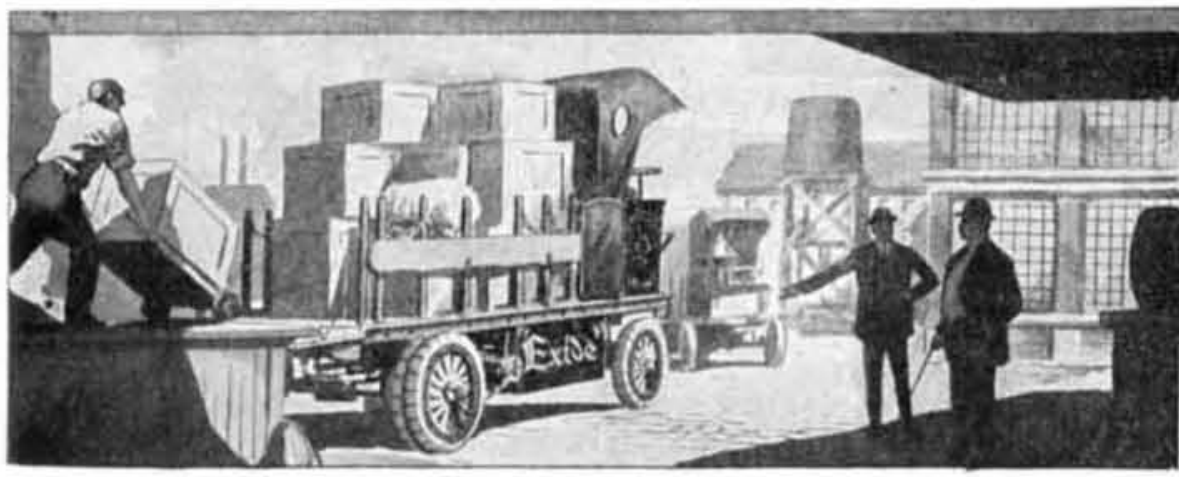

WHEN YOU BUY ONE OF

\section{The 4"Exide" Batteries}

"Exioe", "Hpcap-Exioe", “Tbin-Exiסe", "1ronclao-Exioe"

\section{YOU BUY SERVICE}

And service is what you are really after, Mr. Man. That's where the economy of quality comes in. You might buy any battery and get a certain amount of satisfaction - at first. But it's the years of satisfaction that total up in the profit column-the service that is unfailingly excellent over an extended period of time.

The Four "Exido" "Batteries are long time batteries. They give a continuity of service superior to that of any other batteries on the market. They are dependable under any extremes of either hot or cold weather, and do not stall on hills nor when starting heavy loads.

They give satisfactory service throughout their entire life.

If you are about to purchase a new electric truck, or feel that you are not getting the best service from your present ones, by all means investigate the Four "IExide" Batteries. One of them is perfectly suited to the service requirements of whatever "Electric" you prefer, under whatever conditions it is used.

\section{THEELECTRICSTORAGE BATTERYCO.}

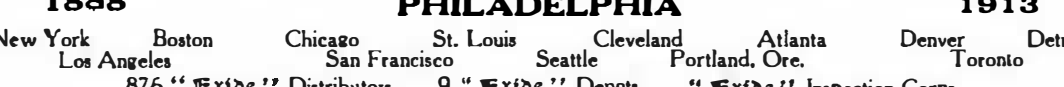

876 " Exibe" Distributors 9 " Exibe" "Depots " Exidee" Inspection Corps
Use the "Exide" Battery for Gas Car Lighting, Starting or lgnition
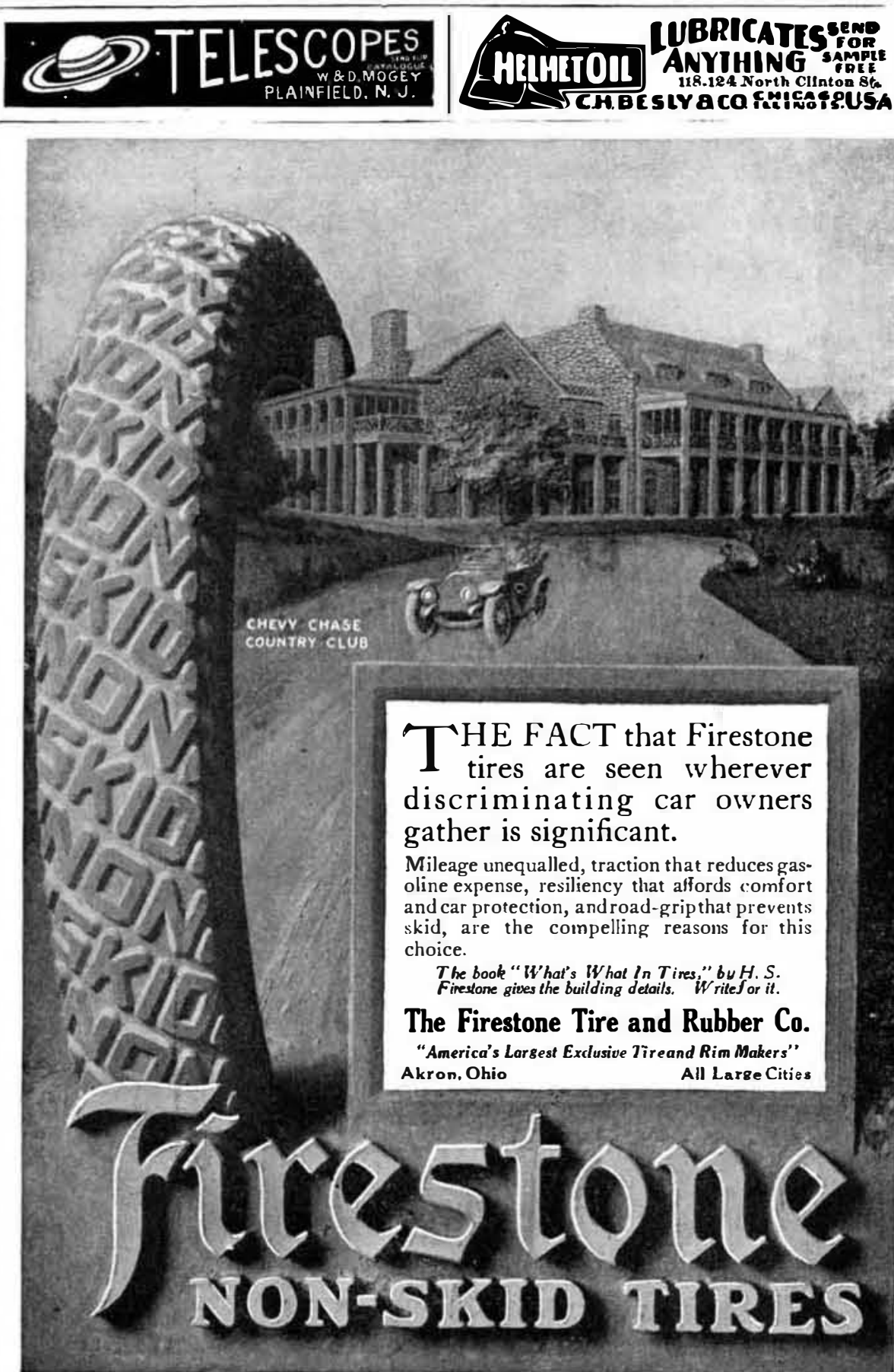